IZA DP No. 6898

Indebted and Overweight:

The Link Between Weight and Household Debt

Susan L. Averett

Julie K. Smith

October 2012

Forschungsinstitut

zur Zukunft der Arbeit

Institute for the Study

of Labor 


\title{
Indebted and Overweight: The Link Between Weight and Household Debt
}

\author{
Susan L. Averett \\ Lafayette College \\ and IZA
}

\section{Julie K. Smith}

Lafayette College

\section{Discussion Paper No. 6898 \\ October 2012}

\author{
IZA \\ P.O. Box 7240 \\ 53072 Bonn \\ Germany \\ Phone: +49-228-3894-0 \\ Fax: +49-228-3894-180 \\ E-mail: iza@iza.org
}

Any opinions expressed here are those of the author(s) and not those of IZA. Research published in this series may include views on policy, but the institute itself takes no institutional policy positions. The IZA research network is committed to the IZA Guiding Principles of Research Integrity.

The Institute for the Study of Labor (IZA) in Bonn is a local and virtual international research center and a place of communication between science, politics and business. IZA is an independent nonprofit organization supported by Deutsche Post Foundation. The center is associated with the University of Bonn and offers a stimulating research environment through its international network, workshops and conferences, data service, project support, research visits and doctoral program. IZA engages in (i) original and internationally competitive research in all fields of labor economics, (ii) development of policy concepts, and (iii) dissemination of research results and concepts to the interested public.

IZA Discussion Papers often represent preliminary work and are circulated to encourage discussion. Citation of such a paper should account for its provisional character. A revised version may be available directly from the author. 


\section{ABSTRACT \\ Indebted and Overweight: The Link Between Weight and Household Debt}

There is a substantial correlation between household debt and bodyweight. Theory suggests that a causal relationship between debt and bodyweight could run in either direction or both could be caused by unobserved common factors. We use OLS and Propensity Score Matching to ascertain if household debt (measured by credit card indebtedness and having trouble paying bills) is a potential cause of obesity. We find a strong positive correlation between debt and weight for women but this seems driven largely by unobservables. In contrast, men with trouble paying their bills are thinner and this is robust to various specification checks.

JEL Classification: I10, I12, I14

Keywords: $\quad$ obesity, credit card debt, propensity score matching

Corresponding author:

Susan L. Averett

Department of Economics

Lafayette College

Easton, PA 18042

USA

E-mail: averetts@lafayette.edu

\footnotetext{
* The research uses data from Add Health, a program project designed by J. Richard Udry, Peter S. Bearman, and Kathleen Mullan Harris, and funded by a grant P01-HD31921 from the Eunice Kennedy Shriver National Institute of Child Health and Human Development, with cooperative funding from 17 other agencies. Special acknowledgment is due Ronald Rindfuss and Barbara Entwisle for assistance in the original design. Persons interested in obtaining Data Files from Add Health should contact Add Health, The University of North Carolina at Chapel Hill, Carolina Population Center, 123 W. Franklin Street, Chapel Hill, NC 27516-2524 (addhealth@unc.edu). No direct support was received from grant P01-HD31921 for this analysis.
}

We thank Mark Anderson, Barry Hirsch, Robert Moffitt, Robert Plotnick, Judith Shinogle, Muzhe Yang and participants of the 2011 Meetings of the Southern Economic Association in Washington D.C. for invaluable comments and advice. In addition, we thank Todd Elder for sharing his STATA program to obtain the estimates in table 7 . All remaining errors are our own. 
Can you afford to be fat? There's a link between weight gain and financial drain. So get ready for some belt tightening because in order to trim your waist you need to trim your debt. $\sim \mathrm{Dr} . \mathrm{Oz}$

If you had credit card debt...the next thing I found about them was they were overweight, it was like this burden, created this excess that wanted to make them eat and eat and eat. So when you're not doing well with your money it shows up in your health. Suze Orman $^{1}$

There is a substantial correlation between household debt and health. Individuals with less healthy lifestyles are more likely to hold debt (Grafova, 2007). However, unlike what discussions in the popular media may imply, a causal link between debt and health has not been firmly established. Economic theory suggests that a causal relationship between debt and health outcomes could run in either direction or both debt and health could be caused by unobserved common factors such as risk aversion, self-control (impulsiveness) and time preferences (Grafova, 2007).

In this paper, we use data from the National Survey of Adolescent Health (Add Health) to test whether financial hardship affects body weight. We divide our sample into two groups: men and women, explore two different types of indebtedness: holding credit card debt and having trouble paying bills, and three health outcomes: overweight, obese and Body Mass Index (BMI). We use both Ordinary Least Squares (OLS) and Propensity Score Matching (PSM) to investigate the relationship that exists between financial hardship and bodyweight. Using OLS, we find that credit card debt is positively correlated with being overweight or obese for both men and women even when controlling for many covariates (age, marital status, education, race, financial characteristics and measures of risk/impulsivity). For women, having credit card debt is also positively and significantly correlated with BMI. Interestingly, having trouble paying bills is negatively correlated with the probability of being overweight or obese for men but positively and significantly correlated with all three outcomes for women. Using PSM which, by matching on observables, makes explicit the comparison group, we find very similar results for both men and women. Therefore, PSM bolsters our confidence in the OLS results. We also conduct several sensitivity analyses which suggest that unobservables may potentially play a large role in this relationship.

\footnotetext{
${ }^{1}$ http://www.doctoroz.com/videos/suze-orman-lose-weight-get-rich-pt-1
} 


\section{Previous Research on Debt and Obesity}

Theoretically, there are competing explanations that may explain the relationship between debt and obesity. A direct causal relationship running from debt to obesity is possible if those in debt must cut back on food expenditures and thus rely on more calorie dense foods hence gaining weight. Along similar lines, indebtedness can cause substantial stress and this may manifest itself in excess caloric intake. Finally, those in debt may also suffer from food insecurity and behavioral biology indicates that those who are food insecure may develop eating habits that lead to being overweight (Smith, Stoddard and Barnes, 2009). Consistent with these three explanations, we would expect a positive relationship between being indebted and being obese. On the other hand, the "new consumerism" as postulated by Schor (1998) may lead even wealthier individuals to consume beyond their financial means. Under this explanation, individuals who accrue debt may not necessarily gain weight (since appearances may matter more to this group and they can afford to join a gym) indicating that a negative relationship between debt and obesity may exist. Finally, a third factor such as impulsivity might cause an individual to become indebted and also overweight because eating and spending are impulsive behaviors.

Many studies have examined socio-economic status (indicated by education, occupation, wealth and income) and its relationship to health and health behaviors but determining a direction of causality can be elusive. ${ }^{2}$ In addition, there are several papers that specifically examine the link between health and debt (Drentea and Lavrakas, 2000; Lyons and Yilmazer, 2005; Grafova, 2007; Smith, Stoddard and Barnes, 2007; Keese and Schmitz, 2010; Lau and Leung, 2011). These papers investigate the relationship between debt and health using a variety of econometric techniques.

Drentea and Lavrakas (2000) test whether credit card debt and stress regarding debt are associated with health using a 1997 representative survey of adults in Ohio. They investigate several questions; 1) how is credit card debt and stress related to debt correlated with health, 2) is the effect stronger than income on health measures, 3) if an effect exists, is it stronger for blacks than whites? The health outcomes they use include own health, body mass index (BMI), smoking, and drinking. The debt indicators they use include debt/income ratio, carrying an unpaid balance, amount of credit line used, charging on more than two cards, and a constructed

\footnotetext{
${ }^{2}$ See Deaton (2002) for a discussion of the issues.
} 
debt stress index. Using OLS hierarchical regression analysis, Drentea and Lavrakas find that having a higher debt/income ratio is associated with worse health either measured or selfreported. They find little evidence that credit card debt is more important than income in explaining health outcomes and behaviors. Finally, there is no evidence to support that credit card debt or stress due to debt can explain the correlation between race and health outcomes.

Lyons and Yilmazer (2005) use data from the Survey of Consumer Finances (SCF) to examine the relationship between financial strain (measured at the household level) and the selfreported health of the head of household. The issue of endogeneity is addressed by using Instrumental Variables (IV) and a representative sample of the US population. They define financial strain as one of the following: 1) delinquent on any loan payment for two months or more, 2) high leverage, 3) little cash on hand. The measure of health used is self-reported health. Lyons and Yilmazer use two-stage probit models to account that financial strain can be both the cause and the consequence of poor health. They do not find evidence that any of the three financial strain measures considered leads to poor health; therefore in their sample it is unlikely that the causality runs from financial strain to worse health.

Grafova (2007) specifically examines how households’ non-collateralized debts are correlated with health behaviors (obese, overweight, smoker). She finds that there is not a causal relationship between debt (credit card and student loans) once controlling for covariates and medical expenditures using fixed effects. The data are from the Panel Study of Income Dynamics (PSID) and she examines married working age couples to get at the household nature of debt. She does find a higher correlation; men who are overweight or obese and women who smoke or are obese are more likely to live in households with non-collateralized debt. However, her results are smaller in magnitude and no longer statistically significant when she controls for fixed effects. It is unclear if this lack of significance is due to having controlled for family level unobservables through the use of fixed effects or if it is because the fixed effects estimates are less precisely estimated (the standard errors are two to three times larger for the fixed effects estimates). Grafova hypothesizes that unobserved factors affect both health and debt and therefore explain the observed correlation.

Smith, Stoddard and Barnes (2009) examine the relationship between economic insecurity measured by changes in the probability of becoming unemployed, drops in real household annual income, and variations in an individual's volatility of income and weight gain 
using the 1979 National Longitudinal Survey of Youth (NLSY79). Their study focuses on men and finds that an increase in any of their economic insecurity measures is positively correlated with weight gain. Using an IV approach with state-level variables such as the state-level minimum wage and median income level, Smith, Stoddard and Barnes (2009) conclude that their earlier OLS results are confirmed by the IV approach and support that economic insecurity may lead to weight gain. In addition, they examine whether a larger social safety net can offset the negative consequences of economic insecurity on weight gain and find that it does.

Keese and Schmitz (2010) use German panel data to analyze the effect of debt on health outcomes. They use three different estimation methods to get at the causal relationship: fixed effects, subsample of the continually employed, and lagged debt variables. The measures of debt that they examine focus on the ability to repay debts; therefore they use the ratio of consumer credit repayments to household net income, ratio of home loan repayments to household income and a binary variable which indicates a household is overindebted. Overindebted households have net income after accounting for loan repayments less than the social assistance level. The health measures examined are a self-reported health satisfaction, a mental health score and obesity. The results from their estimations show that the indebted are more likely to have lower health satisfaction, lower mental health and be overweight.

Recently, Lau and Leung (2011) use data from the U.S. Health and Retirement Survey to examine the effect of mortgage debt on several indicators of health including self-assessed health and obesity. Their OLS estimates suggest that there is a positive effect of mortgage debt on the probability of being obese for individuals over 50 years of age. To identify the causal effect of debt on obesity they employ two strategies. The first is an IV approach using the state level FMHPI (Freddie Mac Housing Price Index) as their instrument of mortgage debt. The second identification approach is a difference-in-differences approach where they use the decline in housing price by state over the 2004-2008 timeframe. States with housing price declines of 20 percent or more are the "treated" states. In both cases, they find a positive and significant effect of mortgage debt on obesity.

The previous empirical literature does not reach a consensus on whether obesity causes debt accumulation, debt causes obesity or if both obesity and debt are caused by common unobserved factors. We complement and extend this literature by using data from the AddHealth and applying a matching estimator. 


\section{Econometric Methods}

Our goal is to ascertain the causal impact of debt on obesity. However, since we have observational data and lacking a credible natural experiment, we have to be particularly cognizant of unobservables which may bias our estimates. The ideal empirical method would be to randomly assign individuals to financial hardship (in our case holding credit card debt or having trouble paying bills) and then measure their obesity status. In the absence of such an experiment, we have to rely on other methods. In OLS, biased estimates of the effect of the treatment (credit card debt and trouble paying bills) on being overweight or obese are obtained if we fail to include all the characteristics that affect both financial hardship and obesity. In addition, even if all the correct control variables are included, the linear specification of OLS could be incorrect (Reynolds and DesJardins, 2009). Furthermore, if those in debt differ in unobserved ways from those who are not in debt, between-group comparisons may reflect those differences rather than the impact of financial hardship per se. In our case, we are particularly worried about reverse causality. It is plausible that upon becoming obese or overweight one could spend more money as a coping mechanism and thus end up in debt. One way to address this reverse causality is to use IV models. This method relies upon having plausible instruments. In our case a plausible instrument would be one that is correlated with financial hardship but not with obesity. Lacking such an instrument in the data, we use PSM to investigate the strength of our OLS results. ${ }^{3}$

PSM relies on the "conditional independence assumption”: all factors related to receiving a treatment are observed and measured (Black and Smith, 2004). Such methods address "selection on observables" but do not fully deal with the selection problem because unobserved characteristics are likely to influence both financial hardship and body weight.

The PSM method creates an appropriate control group for the treatment group. In our case, we compare two groups who are otherwise observably similar, but one group receives a treatment (credit card debt or trouble paying bills) and the other group does not (no credit card debt or trouble paying bills). Under certain assumptions, the difference in the outcomes of the

\footnotetext{
${ }^{3}$ An advantage of PSM is that the matching estimators are non-parametric. Another possible method would be fixed effects. Fixed effects is not feasible in our case since the debt questions are not repeated every year of the four waves of the AddHealth. Furthermore, as noted by Grafova (2007) fixed effects cannot uncover if there is reverse causality.
} 
two groups can be attributed solely to the treatment (i.e. to having credit card debt or to having trouble paying bills). This is often termed a "selection-on-observables" approach.

Using data from the AddHealth, discussed in more detail in the next section, we effectively create a counterfactual for individuals in the treatment group using individuals from the control group who are most similar in terms of these covariates. Specifically, each observation in the treatment group is matched with one or more observations in the control group. Under certain assumptions, the average difference in outcomes can then be attributed to the presence of credit debt or trouble paying bills (Rosenbaum \& Rubin, 1983).

To illustrate our method, we define the following for credit card debt treatment: $Y_{1}$ : outcome of a young adult with credit card debt (exposed to the treatment) $Y_{0}$ : outcome of a young adult without credit card debt (not exposed to the treatment) $D$ : indicator of credit card debt (the treatment) $X$ : set of covariates

Matching requires the assumption that all relevant differences between the two groups will be captured by the set of covariates (Dehejia, and Wahba, 2002). That is: $\left(Y_{0}, Y_{1}\right) \perp D \mid X$. Young adults with credit card debt are matched with a control group of young adults who have no credit card debt, with whom the distribution of the covariates is as close as possible to the group with the treatment. PSM provides a natural method for weighting each of the covariates, thus avoiding the problem of finding an exact match for the treatment group. While finding an exact match would severely limit the number of possible covariates to be matched on, PSM allows matching on a large number of covariates by collapsing the relevant information into a single index, or "propensity score”. The propensity score (PS) is defined as the probability of receiving the treatment conditional on the set of covariates. Thus, $P S(X)=P(D=1 \mid X)$. In practice, we estimate the propensity score using a logit model including a large number of covariates ${ }^{4}$. Using the obtained estimates, we predict the likelihood of having credit card debt (conditional on the observables), regardless of whether individuals actually experienced credit card debt. Then, we can, in the parlance of the treatment literature, calculate the Average Treatment effect on the Treated (ATT), ATT $=E\left(\left(Y_{1}-Y_{0} \mid T=1\right)=E\left(Y_{1} \mid T=1\right)-\right.$ $E\left(Y_{0} \mid T=1\right)$. The ATT in our study is the effect of having credit card debt for those who have

\footnotetext{
${ }^{4}$ The list of covariates in discussed further in the results section and appendix table 3.
} 
credit card debt, and it measures the effect of credit card debt on our outcomes. The ATT is modified when using PSM by using the assumption $E\left(Y_{0} \mid T=1, \hat{P}(X)\right)=E\left(Y_{0} \mid T=0, \hat{P}(X)\right)$.

There are various matching methods each of which has advantages and disadvantages. Most importantly, within finite samples there is a tradeoff between bias and variance of the ATT estimates when using different matching methods (Reynolds and DesJardins, 2009). Following Anderson (2012) we use several different matching methods including nearest neighbor, $k$ nearest neighbors, nearest neighbor within caliper, kernel, local linear regression, and radius. We describe each below.

Nearest neighbor matches each observation in the sample that has credit card debt with an observation in the sample that does not have credit card debt with a similar propensity score (similar observable characteristics). We use nearest neighbor matching with replacement. $K$ nearest neighbor is similar to nearest neighbor except $k=3$ instead of $k=1$.

Caliper and radius matching both make matches within a range or bandwidth $(h)$. Both do not make matches when the nearest match is outside of the interval determined by the bandwidth and the observation will be dropped from the sample. In addition, in radius matching all matches found within the interval are equally weighted. We selected several bandwidths to check the robustness of our results. In our empirical work, we use several bandwidths ( $h=.001$, $h=.0001, h=.00005)$ for the caliper matching and $(h=.001)$ for the radius matching (Anderson, 2012; Reynolds and DesJardins, 2009).

Related to caliper and radius matching is kernel matching and local linear regression (LLR). Once again these two methods match to many control observations (no credit card debt). However, instead of equal weights on all matches within an interval the weights in kernel and LLR are determined by how similar the match is. In our empirical work, we use $h=.06$ for kernel matching and $h=.18$ for LLR matching. (Anderson, 2012; Reynolds and DesJardins, 2009)

\section{Data}

As noted above, we use data from the AddHealth, a school-based longitudinal study of a nationally representative sample of adolescents in grades 7 to 12 in the United States which started during the 1994-5 school year. ${ }^{5}$ We use Wave I when the individuals were first

\footnotetext{
${ }^{5}$ More details on this dataset are available at http://www.cpc.unc.edu/projects/addhealth/design/designfacts.
} 
interviewed and were aged 11 to 21 years and Wave III which was fielded between July 2001 and April 2002 when respondents were 18 to 28 years old. These data are particularly wellsuited for our analysis as we have information on financial hardship and obesity as well as a rich array of covariates.

In Wave I, 20,745 individuals completed the in-home interview. We drop 5,602 who were not interviewed in both Waves I and III. In addition, we drop individuals who did not report their race (250) and those who were missing information on trouble paying bills (10) or had missing information on credit card debt (25). We lose an additional 340 individuals for whom we lack information on height and weight, another 23 who did not report if they had a credit card, and 3 whose marital status could not be determined. In addition, we drop those for whom information on gambling (41), volunteering (30), lottery playing (5), high school drinking behavior (25), having savings account (9), thinking smart compared to others (41), believing it is likely that they will go to college (56), and usual hours of work in the summer (140) was missing. When there was no information on an individual's religiosity (24), high school smoker status (8), the propensity to take risks (122), high school GPA (359) and if the respondent had ever taken something from a store without paying for it (40) we dropped those individuals. Deleting these individuals leaves us with a final sample of 13,599 men and women.

\section{Outcome Variables}

We use self-reported height and weight to calculate the individual's BMI. BMI is not an optimal measure of obesity because it is unable to distinguish between lean body mass and body fat (Burkhauser and Cawley, 2008 and Johansson et al., 2009). However, it is the only measure in our data and widely in social science research. We create an obesity indicator for those with a BMI greater than or equal to 30 to denote obese and one greater than or equal to 25 to denote overweight or obese and we also use the BMI itself as an outcome although we recognize that changes in BMI that do not move an individual into the overweight category are not necessarily health risks.

\section{Treatment variable (Measures of financial hardship)}

We examine two measures of financial hardship: whether the respondent reports having any credit card debt or having had trouble paying bills in the past month. Because these types of financial hardship can arise for various reasons and their impact on health is likely to be quite 
different, we chose to examine them separately. Specifically, respondents are asked” Do you [if the respondent is married, add: "or your \{HUSBAND/WIFE\}"] have any credit card debt?" which we use to create our credit card debt variable. Also, we create a binary variable equal to 1 if the respondent reported having trouble paying various bills including telephone, gas and electric. Appendix table 1 details the construction of this variable. Variables used to estimate the propensity score

To estimate the propensity score, we include a rich array of control variables that potentially influence both the probability of financial hardship and body weight. From Wave I, measured when the individuals were in high school, we include parental education and father's employment status, whether the family was on welfare, whether the respondent drank or smoke in high school, whether the respondent was breastfed, whether they had ever stolen anything, whether they thought they were smarter than others, usual hours of work in the summer, mother's obesity status, whether their mother was a binge drinker, the adolescent's high school GPA and whether the adolescent believed it was likely they were going to go to college. We also include several contemporaneous variables; the respondent's current age, race, marital status, income, an index of their propensity to take risks ${ }^{6}$, a measure of religiosity, ${ }^{7}$ whether they have gambled for money including casino games, horse racing, bingo and sporting events, whether they have played the lottery, if they volunteer or have a savings account ${ }^{8}$. In addition, in the models where the treatment is having trouble paying bills, we include an indicator for whether the individual has a credit card.

\section{Empirical Results}

Our results are presented in tables 1 through 7 . In table 1, we present sample means for our outcome variables by sex and our two measures of financial hardship status - credit card debt and reported trouble paying bills. Both males and females who are in credit card debt have higher BMIs and are more likely to be overweight or obese. Specifically, for women, 20.4 percent of women in credit card debt are obese while only 18.6 percent of those not in credit card debt are obese and these unadjusted means are statistically different from each other.

\footnotetext{
${ }_{7}^{6}$ See Appendix table 2 for details on the creation of this variable.

7 Respondents are asked how religious they are and can respond not at all, slightly, moderately or very.

${ }^{8}$ See Caliendo and Kopeinig, 2005 for an excellent discussion of the selection of variables for the propensity score.
} 
Turning to our second measure of financial hardship, having trouble paying bills, the patterns observed above for women are remarkably similar. However, we see that men who do not report trouble paying their bills are significantly more likely to be overweight yet the difference in BMI across these two groups is not statistically significant. ${ }^{9}$

Tables 2a and 2b presents the sample means for all of our covariates by gender and our two measures of financial hardship. Asterisks indicate when variables are statistically different for those in credit card debt or having trouble paying bills versus those who are not by gender.

Tables 3a and 3b present the results from OLS models of regressing the three outcomes on credit card debt or trouble paying bills and the covariates. Focusing first on credit card debt (table 3a), for women, credit card debt is a positive and significant predictor of BMI and of the probability of being overweight or obese. Married women, black and Hispanic women and those who are more religious have higher BMIs and are more likely to be overweight or obese. Maternal obesity and having been breastfed are significant predictors of current body weight in the expected direction. Parental smoking and volunteering exert a positive and significant effect on all three outcomes. Being a better student in high school (GPA) is negatively and significantly correlated with all of the outcome variables. Having had a parent on welfare while in high school positively affects BMI and the probability of being obese while having educated parents, negatively affects all three outcomes. Women who thought they were smarter than others in high school are more likely to be obese, while those with a greater propensity to take risks have a significantly higher BMI. Women who stole in high school are significantly likely to have a lower BMI and less likely to be overweight. Women whose fathers were management or professionals were less likely to be overweight than women whose fathers had other occupations. Once we have controlled for other covariates, having a higher income is generally associated with a lower body weight for women, although the effect is not always statistically significant. Finally, women who have savings accounts are 3.2 percentage points less likely to be obese, 4.9 percentage points less likely to be overweight or obese and have lower BMIs, all of which are statistically significant.

\footnotetext{
${ }^{9}$ Appendix table 3 presents the correlations of the two financial hardship measures for men and women. Of women $49 \%$ have trouble paying bills and are in credit card debt and of men $42 \%$ have trouble paying bills and are in credit card debt. Additionally, of women 31\% have trouble paying bills but are not in credit card debt and of men $28 \%$ have trouble paying bills but are not in credit card debt.
} 
For men having credit card debt leads to a 2.6 percentage point increase in the probability that they are overweight or obese but has no significant effect on BMI or the probability of being obese. Similar to women, married men are more likely to be heavier than their unmarried counterparts. Compared to white men, Hispanic men and men of other races are heavier while black men are significantly more likely to be obese than white men and they have a higher BMI. Men who play the lottery, are more religious or whose mother's were obese have higher BMIs and are more likely to be overweight or obese. Unlike the case of women, father's occupation has no effect on the outcomes for men. Being breastfed and having a higher high school GPA has a significant negative effect on all three outcomes. Men who smoked in high school have a significantly lower BMI and are less likely to be overweight but there is no effect on the probability of being obese. Parental smoking exerts a positive, significant effect on BMI and men whose parents smoked are 2.8 percentage points more likely to be obese. Interestingly, having a mother who was a binge drinker or having a parent who received welfare significantly lowers the probability of being obese for men; although, it does not affect the other two outcomes. Men who stole in high school have significantly lower BMI and are less likely to be obese.

Turning to table $3 \mathrm{~b}$ where the treatment is having trouble paying bills, for women we find that women who have trouble paying their bills are 4.0 percentage points more likely to be obese, 4.7 percentage points more likely to be overweight or obese and have BMIs that are 0.73 points higher than those who do not have trouble paying their bills. For men, the effect of having trouble paying bills is negative (4.1 percentage point decrease) and statistically significant predictor of the probability of being overweight or obese (but exerts no statistically significant effect on the BMI or probability of being obese). The other covariates for both men and women are remarkably similar in sign, significance and magnitude.

Our PSM results are presented in tables 4a (credit card debt) and $4 \mathrm{~b}$ (having trouble paying bills). ${ }^{10}$ These models may have an advantage over OLS in that they make explicit the comparison group and they reweight the estimates such that the treatment and control group are observationally equivalent in terms of their covariates. In addition, PSM uses only the matched

\footnotetext{
${ }^{10}$ The results of the logit models used to estimate the propensity score are presented in Appendix Table 3. We only included whether an individual had a credit card in the matching equation of having trouble paying bills since people may use a credit card to pay bills. In order to pass the balancing property for men, it was necessary to drop whether they had volunteered. It is worth noting that we pass the balancing property.
} 
observations to calculate the ATT which is important because it establishes comparability between the treatment and control groups; i.e. both are on the common support (Zhao, 2004) Furthermore, the PSM method allows for heterogeneity in the treatment effect across populations (i.e. the ATT is calculated by averaging individual-level differences in behavior between the treated and untreated groups thus reducing the estimation bias) and PSM does not impose any functional form restrictions (Zhao, 2004; Conniffe et al., 2000; Rubin and Thomas, 2000). In addition, there is evidence that PSM, under certain conditions yields estimates that compare favorably with those from experimental studies (Smith and Todd 2001; Michalopoulos et al. 2004). ${ }^{11}$

For both men and women in table 4a, there are two patterns worth noting. First, the OLS and PSM results are remarkably similar indicating that there is little selection bias. Secondly, the results from the different matching methods are quite similar in magnitude and significance with the occasional exception of the within caliper results. This may be due to the fact that as the caliper becomes smaller the number of matches made decreases but the matches are of higher quality; however, the variance of the estimates increases (Anderson, 2012). ${ }^{12}$

For both men and women, as noted in table 4b, the results from the PSM are incredibly similar and more robust than the results when the treatment is credit card debt. It is rarely the case that the precision of the estimates is affected by the matching estimator.

Overall, these results indicate that women have higher BMIs if they are in credit card debt but there is only a modest increase in the probability of being overweight or obese for women in credit card debt. However, the effect of having trouble paying bills on our outcomes is stronger. In particular, according to our PSM results, women who have trouble paying their bills are somewhere between 3.7 and 5.2 percentage points more likely to be overweight or obese and 3.3 to 4.4 percentage points more likely to be obese.

For men, we find no significant effect of financial hardship on BMI or the probability of being obese. However, we find opposite effects for the different types of financial hardship on the probability of being overweight or obese. In particular, we find that men with credit card debt

\footnotetext{
${ }^{11}$ One of these conditions is having a data set with a wide array of covariates. This allows the researcher to control for as much observable heterogeneity as possible. Our data is consistent with this.

${ }^{12}$ A number of studies find differences between OLS and PSM results (Anderson, 2012; Plotnick, 2012; Belfield and Kelly, 2012). Recent research by Shah et al. (2005) and Stürmer et al. (2006) suggests that it is often the case that the results from PSM are not that different from other multivariate methods (e.g. Caliendo and Lee, forthcoming).
} 
are more likely to be overweight or obese (ranging from 2.6 to 4.7 percentage points) but less likely to be overweight or obese if they have trouble paying their bills (ranging from -3.5 to -4.7 percentage points). In the next section, we undertake several robustness checks.

\section{Robustness Checks}

In addition to employing a variety of matching methods, we also conduct several specification checks of our results. One that is suggested by Dehejia (2005) is to rerun the logit that creates the propensity score to see how sensitive the results are to changes in the specification of the propensity score. When we did this by including higher order terms for all of our continuous covariates we found that in general, our results are not sensitive to these changes in the estimation of the propensity score (these results are available upon request). Specifically, it is nearly always the case that when we report a significant effect in tables $4 \mathrm{a}$ and $4 \mathrm{~b}$, the statistical significance remains and the point estimates are reasonably close.

Another popular specification test is the Rosenbaum bounds test. Recall that we can only match on observables and it is possible that unobservables are distributed quite differently across individuals with the same propensity score. This test is used to assess how large the unobservable heterogeneity would have to be to overturn the matching estimator results when those results are statistically significant (Caliendo and Kopeinig, 2005). In our application, it is likely that any bias from unobservables is upward. For example, if the unmeasured factor is impulsiveness then we expect the unobservables to be positively correlated with financial hardship and body weight. In other words, we think any plausible unobservables are going to be correlated either positively or negatively with our outcome (body weight) and our treatment (experiencing financial hardship).

We report the p-value of the Mantel-Haenszel (MH) statistic for the upper bound given our belief that any bias would be upward. These are presented for the kernel matching only ${ }^{13}$ and only for the overweight/obese outcome because that is where we most often obtain significant results. The Rosenbaum bounds test presents the likelihood that two individuals would have different outcomes given the same observable characteristics. $\Gamma$ represents the odds that two individuals who are observationally equivalent differ in their treatment effect. If $\mathrm{e}^{\gamma}=1$

\footnotetext{
${ }^{13}$ Henry and Yi (2009) note that kernel matching is preferred as it produces the least bias compared to an experimental estimate.
} 
then two individuals have the same probability of being exposed to financial hardship. As $\Gamma$ rises the odds of two observationally equivalent individuals being in financial hardship increasingly differs. The p-value of the Mantel-Haenszel test statistic shows whether that difference is statistically significant.

The results are in table 5. For men with credit card debt, at $\mathrm{e}^{\gamma}=1.2$ the $\mathrm{MH}$ statistic becomes insignificant which indicates that if there were a 20 percent difference in unobservables across control and treatment groups the positive and significant (2.9 percentage points more likely to be overweight or obese result in table $4 \mathrm{a}$ ) would be overturned. However, at $\mathrm{e}^{\gamma}=1.35$, the p-value becomes .06. This pattern, where the MH statistic goes from significant to insignificant and back to significant, indicates a significant negative treatment effect; i.e. the relationship between credit card debt and overweight becomes negative (Becker and Caliendo, 2007). In other words, unobservable heterogeneity that is 35 percent different between control and treatment groups could reverse the sign of our effect. For women with credit card debt, the MH statistics for overweight/obese are similar to what we find for men. The critical values of $\mathrm{e}^{\gamma}$ for women are 1.05 and 1.25 indicating that these results are slightly more sensitive to unobservables than are those for men.

For men who report trouble paying their bills, although the coefficient estimates from the matching are negative and significant we maintain our assumption that the bias would be upward. In this case $\mathrm{MH}$ statistics are significant up to $\mathrm{e}^{\gamma}=2$ indicating that for any reasonable difference in the unobservables our results are robust. For women who have trouble paying their bills, the coefficient on overweight/obese is positive and significant and the MH statistic becomes insignificant at $\mathrm{e}^{\gamma}=1.5$ and then the treatment effect would become negative at a $\mathrm{e}^{\gamma}$ =1.7. While this sensitivity analysis indicates how bias from unobservables may alter our inferences it in no way tells us if such bias is present (Aakvik, 2001).

A key identification issue in this research is omitted variable bias. As noted earlier, a plausible unobservable variable in our case is an individual's level of impulsivity. If impulsive behavior is the cause of both financial hardship and obesity then our estimates of the effect of financial hardship on obesity are biased. We can use some of the questions from our risk preference index as measures of impulsivity and then examine the extent to which individuals differ given that they have the same level of impulsivity. If the control variables provide all the important information to isolate the effect of debt on obesity, it should be the case that for those 
who are impulsive (or not impulsive) their mean characteristics do not differ by whether they have debt.

Specifically, within our risk preference variable measured in Wave III are three questions that can arguably be interpreted as measures of impulsivity. These are:

- I often do things based on how I feel at the moment

- I sometimes get so excited that I lose control of myself

- I often follow my instincts, without thinking through all the details

In the survey, respondents answer these on a five point Likert scale (see Appendix table 2). We create a variable indicating impulsive behavior equal to one if the individual answered with a five to all three questions. In the case, where there were missing values the variable equals one when the respondent answered with a five to each of the questions answered. Similarly, we created a variable equal to one if the individual answered with a one to all three questions indicating a lack of impulsivity and in the case of missing values the variable equals one when the respondent answered with a one to each of the questions answered.

We then examine the sample means of our Wave III variables by each of financial hardship measures for those with low and high impulsivity. The intuition is that these sample means should not vary for those who are impulsive; i.e. those who exhibit impulsive behavior are going to be observationally equivalent whether are they are in credit card debt. ${ }^{14}$

Our evidence is mixed and varies by gender and financial hardship measure. In table 6, where we present the p-values for the null hypothesis that the variable means are equal within impulsivity and gender across debt measures, there are quite a few indications of differences in sample means for impulsive women who do and do not have financial hardship. The differences for impulsive men occur across fewer of the covariates and mostly for the trouble paying bills outcome. Perhaps unsurprisingly, for non-impulsive women there are almost no differences in the means across the covariates. However for non-impulsive men the pattern is nearly identical to impulsive men. This suggests that even with our rich array of controls there still may be some bias in our estimates. Clearly, our covariates do not capture full tendency to be impulsive.

\footnotetext{
${ }^{14}$ We examine the differences in the sample means for our other Wave III variables given that those probably are most relevant to recent weight gain.
} 
Given the lack of clarity from these results we perform additional robustness checks to examine selection on unobservables based on the work of Altonji et al. (2008).

Our results from the PSM hinge on selection being only from observable factors. Altonji et al. (2008) make the argument that researchers can impose different levels of selection on unobservables which are as reasonable as the PSM assumption that there is no selection on unobservables. Specifically, they argue that it is as reasonable to choose selection on unobservables is equivalent to selection on observables. Using a bivariate probit as suggested by Altonji et al. (2008) we can alter the correlation between unobservables and examine whether the estimates are similar to those from OLS and PSM. ${ }^{15}$ The bivariate probit includes one equation regressing the outcome (overweight/obese) on our covariates and financial hardship measures and the other equation regressing the treatment variables (credit card debt and trouble paying bills) on our covariates. To start, we assume there is no correlation between errors $(\rho=0)$ in the two equations of a bivariate probit; assuming $\rho=0$ implies that there are no unobservables that affect both financial hardship and weight. As expected when $\rho=0$, the results in the top panel of table 7 confirm the OLS and PSM results and are similar in size and significance.

Given that we cannot observe impulsiveness, Altonji et al. (2008) also suggest that we can use the amount of selection on observables to proxy for the amount of selection on unobservables. By making this assumption we can assess the importance of unobservable characteristics on our estimates of the treatment effect. Again, we use a bivariate probit and impose the restriction that the correlation on the unobservables in the two equations is equal to the correlation on the observables. Looking at the estimates in the middle panel of table 7 , allowing the selection on unobservables to vary in a similar size as the selection on observables overturns our results except for men who have trouble paying bills reinforcing that the result that men who have trouble paying bills are thinner on average is robust.

Finally, Altonji et al. (2005) and Reynolds (2009) examine how much more selection on unobservables over the selection on observables is needed to overturn the results by examining the ratio of estimated treatment effect to the estimated bias. These results are shown in the bottom panel of table 7. For men with credit card debt, the amount of additional selection on unobservables is small to overturn the results. For men who have trouble paying bills, selection on unobservables needs to be almost five times greater than the selection on observables to

\footnotetext{
${ }^{15}$ For a full explanation of the technical details, see Altonji et al. (2008) and Reynolds (2009).
} 
overturn the result. For women, the additional selection on unobservables needed to overturn the result varies depending on the treatment. The size must be larger for credit card debt than for trouble paying bills.

Overall, these robustness checks do not rule out that there may be a third factor affecting both financial hardship and weight. However, the result that men with trouble paying their bills are thinner is robust. This disparity generates additional research questions about the causes of weight gain in men and women and also demonstrates that not all financial hardship has the same effects on weight gain.

\section{Conclusions}

In this paper, we have attempted to isolate the effect of financial hardship on obesity. This research question seems particularly urgent given the high levels of obesity in the U.S. and the fact that the average American held about \$5000 in credit card debt in 2010 (Connelly, 2010). Given the extent of the obesity epidemic facing the U.S. and its resulting medical costs which have been estimated to be as high as 9.1 percent of total annual U.S. medical expenditures (Finkelstein, Fiebelkorn and Wang, 2003), establishing if there is a causal link between debt and health may provide further impetus for policy makers to enact regulations protecting consumers from financial hardship. One such regulation is contained in the Dodd/Frank Wall Street Reform and Consumer Protection Act of 2010 which states among other things that the new consumer advocate will “(p)romote fairness and transparency for mortgages, credit cards and other consumer financial products and services” (Zhen, 2011).

Although the popular press accepts that credit card debt may cause obesity our results do not fully support that conclusion. We find that women who have trouble paying their bills are

more likely to be obese; however, several robustness checks call into question the validity of this result suggesting that there are important unobservable factors that we are unable to account for in our model, despite matching on a wide array of observable characteristics. Thus, our research suggests that conventional wisdom may be wrong. The exception is that men with trouble paying their bills may actually be thinner than those who do not, and this effect is robust to our specification checks. Thus, despite the fact that we have a rich array of factors to act as controls in our data, it may be the case that there is an outside factor such as impulsivity causing both 
financial hardship and body weight changes. Future research should focus on identification of the causal effect. 


\section{References:}

Aakvik, A. 2001. Bounding a matching estimator: The case of a Norwegian training program. Oxford Bulletin of Economics and Statistics 63 (1): 115-43. 1

Altonji, J.G., T.E. Elder, and C.R. Taber. 2008. “Using Selection on Observed Variables to Assess Bias from Unobservables when Evaluating Swan-Ganz Catheterization,” American Economic Review, 98, 345-350.

Anderson, D. M. 2012. The impact of HIV education on behavior among youths: A propensity score matching approach. Working Paper.

Becker, Sascha O. and Caliendo, Marco, Mhbounds - Sensitivity Analysis for Average Treatment Effects (January 2007). IZA Discussion Paper No. 2542. Available at SSRN: http://ssrn.com/abstract=958699

Belfield, Clive R., and Inas Rashad Kelly. Early education and health outcomes using the U.S. early childhood longitudinal study - birth cohort. Economics \& Human Biology(0).

Black, D., and J. Smith (2003): \How Robust is the Evidence on the Effects of the College Quality? Evidence from Matching," Working Paper, Syracuse University, University of Maryland, NBER, IZA.

Burkhauser, Richard V., and John Cawley. 2008. Beyond BMI: The value of more accurate measures of fatness and obesity in social science research. Journal of Health Economics 27 (2) (3): 519-29.

Caliendo, M., and Kopeinig, S. 2005. Some practical guidance for the implementation of propensity score matching. IZA DP No. 1588.

Caliendo, Marco, and Wang-Sheng Lee. Forthcoming. Fat chance! obesity and the transition from unemployment to employment. Economics \& Human Biology. http://dx.doi.org/10.1016/j.ehb.2012.02.002.

Connelly, E. 2010. Credit card debt drops to lowest level in 8 years. USA Today. 
Conniffe, Dennis, Vanessa Gash and Philip J. O’Connell. 2000. Evaluating state programmes:" natural experiments" and propensity scores. The Economic and Social Review. 31(4): 283 -308.

Deaton, A.S. 2002. "Policy Implications of the Gradient of Health and Wealth," Health Affairs, 21: 13-30.

Dehejia, R. 2005. Practical propensity score matching: A reply to Smith and Todd. Journal of Econometrics 125: 355-64.

Dehejia, R. and S. Wahba. 2002. Propensity score-matching methods for nonexperimental causal studies. Review of Economics and Statistics 84 (1): $151-61$.

Drentea, P., and P. Lavrakas. 2000. Over the limit: The association among health, race and debt. Social Science and Medicine Part f Medical and Social Ethics 50 (4): 517.

Finkelstein, . 2003. National medical spending attributable to overweight and obesity: How much, and who's paying? Health Affairs 22 (3; SUPP): 3.

Grafova, Irina B. 2007. Your money or your life: Managing health, managing money. Journal of Family and Economic Issues 28 (2): 285-303.

Henry, G., and Yi, P. 2009. Design matters: A within-study assessment of propensity score matching designs. Working paper.

Keese, M., and H. Schmitz. 2010. Broke, ill, and obese: The effect of household debt on health. Ruhr Economic Paper No. 234. Available at SSRN: http://ssrn.com/abstract=1735420 or http://dx.doi.org/10.2139/ssrn.1735420

Lau, C., and L. Leung. 2011. Effect of mortgage debt on health. Mimeo. http://www.gc.cuny.edu/CUNY_GC/media/CUNY-GraduateCenter/PDF/Programs/Economics/Seminar\%20papers/Effect-of-mortgagedebt-on-health.pdf

Leuven E. and B. Sianesi. (2003). "PSMATCH2: Stata module to perform full Mahalanobis and propensity score matching, common support graphing, and covariate imbalance testing". http://ideas.repec.org/c/boc/bocode/s432001.html. Version 4.0.4 $\underline{10 \text { nov2010 }}$ 
Lyons, C., and T. Yilmazer. 2005. Health and financial strain: Evidence from the survey of consumer finances. Southern Economic Journal: 873.

Michalopoulos, Charles; Bloom, Howard and Hill, Carolyn. 2004. Can Propensity-Score Methods Match the Findings from a Random Assignment Evaluation of Mandatory Welfare-to-Work Programs? Review of Economics and Statistics 86: 157-179.

Plotnick, Robert. 2012. Childlessness and Use of Health Care by Older Americans. Paper presented at the 2012 meetings of the Population Association of America.

Reynolds, L., and S. DesJardins. 2009. The use of matching methods in higher education research: Answering whether attendance at a 2-year institution results in differences in educational attainment. In Higher education: Handbook of theory and research., 47-97.

Rosenbaum, P. and Rubin, D. 1983. The central role of the propensity score in observational studies for causal effects. Biometrika 70 (1): 41-55.

Rubin, Donald B. and Neal Thomas. 2000. Combining Propensity Score Matching with Additional Adjustments for Prognostic Covariates. Journal of the American Statistical Association, 95:573-585

Schor, Juliet B. 1998. The Overspent American: Upscaling, Downshifting, and the New Consumerism. Basic Books, New York.

Shah, Baiju R. 2005. Propensity score methods gave similar results to traditional regression modeling in observational studies: A systematic review. Journal of Clinical Epidemiology 58 (6): 550-9.

Smith, T., C. Stoddard and M. Barnes 2009. Why the Poor Get Fat: Weight Gain and Economic Insecurity. Forum for Health Economics \& Policy.12(2): Article 5

Smith, Jeffrey and Todd, Petra. 2001. Reconciling Conflicting Evidence on the Performance of Propensity-Score Matching Methods. American Economic Review 91: 112-118.

Stürmer, Til, Manisha Joshi, Robert J. Glynn, Jerry Avorn, Kenneth J. Rothman, and Sebastian Schneeweiss. 2006. A review of the application of propensity 
score methods yielded increasing use, advantages in specific settings, but not substantially different estimates compared with conventional multivariable methods. Journal of Clinical Epidemiology 59 (5): 437.e1,437.e24.

Zhen, Simon. 2011. "Consumer Financial Protection Bureau Website Launched and Open for Suggestions". Mybanktracker.com. Retrieved 2011-02-10.

Zhao, Z. 2004. Using Matching to Estimate Treatment Effects: Data Requirements, Matching Metrics, and Monte Carlo Evidence. Review of Economics and Statistics 86:1, 91-107 


\begin{tabular}{|c|c|c|c|c|c|c|c|}
\hline \multirow[t]{3}{*}{ Table 1: } & \multicolumn{7}{|c|}{ Sample Means for Dependent Variables } \\
\hline & \multicolumn{7}{|c|}{ Men } \\
\hline & All Men & $\begin{array}{l}\text { No Credit } \\
\text { Card Debt }\end{array}$ & $\begin{array}{l}\text { Has Credit } \\
\text { Card Debt }\end{array}$ & Sig. ${ }^{a}$ & $\begin{array}{l}\text { No Trouble with } \\
\text { Bills }\end{array}$ & $\begin{array}{c}\text { Trouble Paying } \\
\text { Bills }\end{array}$ & Sig. ${ }^{a}$ \\
\hline BMI & 26.032 & 25.87 & 26.294 & * & 26.048 & 25.993 & \\
\hline (std) & $(5.28)$ & $(5.34)$ & $(5.17)$ & & $(5.12)$ & $(5.63)$ & \\
\hline Overweight or Obese & 0.516 & 0.495 & 0.55 & * & 0.528 & 0.486 & * \\
\hline Obese & 0.184 & 0.178 & 0.192 & & 0.183 & 0.187 & \\
\hline \multirow[t]{3}{*}{$\mathrm{N}$} & 6,442 & 3,979 & 2,463 & & 4,540 & 1,902 & \\
\hline & \multicolumn{7}{|c|}{ Women } \\
\hline & $\begin{array}{l}\text { All } \\
\text { Women }\end{array}$ & $\begin{array}{l}\text { No Credit } \\
\text { Card Debt }\end{array}$ & $\begin{array}{l}\text { Has Credit } \\
\text { Card Debt }\end{array}$ & Sig. ${ }^{a}$ & $\begin{array}{c}\text { No Trouble with } \\
\text { Bills }\end{array}$ & $\begin{array}{c}\text { Trouble Paying } \\
\text { Bills } \\
\end{array}$ & Sig. ${ }^{a}$ \\
\hline BMI & 25.53 & 25.288 & 25.829 & * & 25.288 & 25.829 & * \\
\hline (std) & $(6.32)$ & $(6.31)$ & $(6.33)$ & & $(6.31)$ & (6.33) & \\
\hline Overweight or Obese & 0.418 & 0.402 & 0.439 & $*$ & 0.402 & 0.439 & * \\
\hline Obese & 0.194 & 0.186 & 0.204 & $*$ & 0.186 & 0.204 & $*$ \\
\hline $\mathrm{N}$ & 7,157 & 3,958 & 3,199 & & 3,958 & 3,199 & \\
\hline
\end{tabular}

a indicates significant at 10 percent level or greater 
Table 2a: Sample Means by Gender and Credit Card Debt Status

\begin{tabular}{|c|c|c|c|c|c|c|c|c|}
\hline \multirow[b]{2}{*}{ Wave III Variables } & \multicolumn{4}{|c|}{ Men } & \multicolumn{4}{|c|}{ Women } \\
\hline & All Men & No Credit Card Debt & Credit Card Debt & Sig. ${ }^{a}$ & All Women & No Credit Card Debt & Credit Card Debt & Sig. $^{a}$ \\
\hline Has a credit card & 0.572 & 0.396 & 0.857 & $*$ & 0.637 & 0.466 & 0.848 & $*$ \\
\hline Volunteer & 0.273 & 0.269 & 0.279 & & 0.303 & 0.3 & 0.306 & \\
\hline Married & 0.149 & 0.116 & 0.203 & $*$ & 0.216 & 0.18 & 0.26 & $*$ \\
\hline Income between $\$ 1$ and $\$ 7$ & 0.151 & 0.168 & 0.123 & $*$ & 0.214 & 0.245 & 0.175 & $*$ \\
\hline Inc between $\$ 8$ and $\$ 3900$ & 0.166 & 0.185 & 0.136 & $*$ & 0.199 & 0.222 & 0.171 & $*$ \\
\hline Inc between $\$ 4000$ and \$11822 & 0.176 & 0.194 & 0.147 & $*$ & 0.199 & 0.203 & 0.193 & \\
\hline Inc between $\$ 12000$ and $\$ 20100$ & 0.219 & 0.204 & 0.242 & $*$ & 0.204 & 0.172 & 0.244 & * \\
\hline Inc between $\$ 20,500$ to $\$ 300,000$ & 0.242 & 0.195 & 0.319 & $*$ & 0.148 & 0.113 & 0.19 & $*$ \\
\hline Income missing & 0.045 & 0.053 & 0.032 & $*$ & 0.036 & 0.044 & 0.026 & $*$ \\
\hline Gambled & 0.646 & 0.604 & 0.713 & $*$ & 0.519 & 0.454 & 0.599 & $*$ \\
\hline Has a savings account & 0.628 & 0.604 & 0.667 & $*$ & 0.649 & 0.634 & 0.667 & $*$ \\
\hline Lottery & 0.637 & 0.588 & 0.717 & $*$ & 0.586 & 0.521 & 0.666 & * \\
\hline \multirow[t]{2}{*}{ Propensity to take risks } & 2.8 & 2.8 & 2.801 & & 2.323 & 2.341 & 2.301 & $*$ \\
\hline & $(0.91)$ & $(0.93)$ & $(0.88)$ & & $(0.87)$ & $(0.89)$ & $(0.83)$ & \\
\hline \multirow[t]{2}{*}{ Age } & 22.022 & 21.791 & 22.395 & $*$ & 21.819 & 21.545 & 22.158 & $*$ \\
\hline & $(1.75)$ & $(1.81)$ & $(1.59)$ & & $(1.76)$ & $(1.81)$ & $(1.63)$ & \\
\hline Religious & 1.311 & 1.328 & 1.283 & $*$ & 1.47 & 1.478 & 1.461 & \\
\hline White & 0.671 & 0.709 & 0.647 & $*$ & 0.657 & 0.657 & 0.658 & \\
\hline Black & 0.21 & 0.18 & 0.23 & & 0.24 & 0.24 & 0.241 & \\
\hline Other race & 0.122 & 0.112 & 0.127 & $*$ & 0.103 & 0.102 & 0.102 & \\
\hline Hispanic & 0.156 & 0.185 & 0.139 & $*$ & 0.159 & 0.142 & 0.128 & $*$ \\
\hline
\end{tabular}


Table 2a continued:

Men

Women

\begin{tabular}{|c|c|c|c|c|c|c|c|c|}
\hline \multirow[b]{2}{*}{ Wave 1 Variables } & & \multirow[b]{2}{*}{ Sig. ${ }^{a}$} & \\
\hline & All men & Credit Card Debt & No Credit Card Debt & & All women & Credit Card Debt & No Credit Card Debt & Sig. ${ }^{a}$ \\
\hline Drank in past 30 days & 0.11 & 0.106 & 0.117 & & 0.071 & 0.072 & 0.069 & \\
\hline Thinks smart compared to others & 0.566 & 0.54 & 0.606 & $*$ & 0.556 & 0.523 & 0.597 & $*$ \\
\hline Likely to go to college & 0.495 & 0.486 & 0.509 & $*$ & 0.623 & 0.6 & 0.653 & $*$ \\
\hline Usual hours of work in summer & 16.479 & 14.752 & 19.268 & $*$ & 13.041 & 11.242 & 15.268 & $*$ \\
\hline Dad had management/professional job & 0.173 & 0.175 & 0.171 & & 0.167 & 0.172 & 0.161 & \\
\hline Dad did not work & 0.04 & 0.04 & 0.04 & & 0.035 & 0.038 & 0.032 & \\
\hline Dad's job unknown & 0.259 & 0.258 & 0.259 & & 0.298 & 0.301 & 0.293 & \\
\hline Dad's job other than management/professional & 0.528 & 0.526 & 0.531 & & 0.5 & 0.489 & 0.514 & $*$ \\
\hline Smoked in high school & 0.187 & 0.182 & 0.196 & & 0.188 & 0.184 & 0.191 & \\
\hline Highest level of parent's education is college & 0.396 & 0.393 & 0.402 & & 0.367 & 0.363 & 0.372 & \\
\hline Highest level of parent's education is some college & 0.201 & 0.186 & 0.226 & $*$ & 0.217 & 0.195 & 0.245 & $*$ \\
\hline Highest level of parent's education is HS diploma & 0.275 & 0.286 & 0.258 & $*$ & 0.282 & 0.288 & 0.273 & \\
\hline Highest level of parent's education is less than HS & 0.095 & 0.099 & 0.088 & & 0.107 & 0.116 & 0.095 & $*$ \\
\hline Highest level of parental education is unknown & 0.032 & 0.035 & 0.027 & $*$ & 0.027 & 0.037 & 0.015 & $*$ \\
\hline Parent received welfare & 0.096 & 0.108 & 0.076 & $*$ & 0.102 & 0.12 & 0.08 & $*$ \\
\hline Parent smoked & 0.23 & 0.232 & 0.226 & & 0.245 & 0.253 & 0.235 & $*$ \\
\hline Mom obese & 0.153 & 0.15 & 0.157 & & 0.158 & 0.152 & 0.165 & \\
\hline Mom was a binge drinker & 0.104 & 0.106 & 0.101 & & 0.105 & 0.107 & 0.102 & \\
\hline Mom's binge drinking unknown & 0.135 & 0.134 & 0.137 & & 0.142 & 0.14 & 0.144 & \\
\hline Mom breastfed & 0.368 & 0.367 & 0.371 & & 0.361 & 0.358 & 0.364 & \\
\hline Unknown if mom breastfed & 0.164 & 0.159 & 0.171 & & 0.157 & 0.155 & 0.159 & \\
\hline High school GPA & 2.677 & 2.653 & 2.717 & $*$ & 2.895 & 2.872 & 2.923 & $*$ \\
\hline & $(0.77)$ & $(0.79)$ & $(0.75)$ & & $(0.75)$ & $(0.78)$ & $(0.71)$ & \\
\hline Took something from a store without paying for it & 0.277 & 0.261 & 0.303 & $*$ & 0.212 & 0.207 & 0.219 & \\
\hline $\mathrm{N}$ & 6,442 & 3,979 & 2,463 & & 7,157 & 3,958 & 3,199 & \\
\hline
\end{tabular}

Note: Income is total personal income before taxes measured in \$.

${ }^{a}$ indicates significant at the $10 \%$ level or greater. 
Table 2b: Sample Means by Gender and Having Trouble Paying Bills

Men

Women

\begin{tabular}{|c|c|c|c|c|c|c|c|c|}
\hline Wave III Variables & All Men & $\begin{array}{c}\text { No Trouble Paying } \\
\text { Bills }\end{array}$ & $\begin{array}{l}\text { Has Trouble } \\
\text { Paying Bills }\end{array}$ & Sig. ${ }^{a}$ & $\begin{array}{c}\text { All } \\
\text { Women }\end{array}$ & $\begin{array}{c}\text { No Trouble Paying } \\
\text { Bills }\end{array}$ & $\begin{array}{c}\text { Has Trouble Paying } \\
\text { Bills }\end{array}$ & Sig. $^{\mathrm{a}}$ \\
\hline Has a credit card & 0.572 & 0.609 & 0.486 & $*$ & 0.637 & 0.466 & 0.848 & $*$ \\
\hline Volunteer & 0.273 & 0.287 & 0.24 & $*$ & 0.303 & 0.3 & 0.306 & $*$ \\
\hline Married & 0.149 & 0.145 & 0.159 & & 0.216 & 0.18 & 0.26 & $*$ \\
\hline Income between $\$ 1$ and $\$ 7$ & 0.151 & 0.145 & 0.167 & $*$ & 0.214 & 0.245 & 0.175 & \\
\hline Inc between $\$ 8$ and $\$ 3900$ & 0.166 & 0.167 & 0.165 & & 0.199 & 0.222 & 0.171 & \\
\hline Inc between $\$ 4000$ and $\$ 11700$ & 0.176 & 0.17 & 0.19 & $*$ & 0.199 & 0.203 & 0.193 & $*$ \\
\hline Inc between $\$ 12000$ and $\$ 20100$ & 0.219 & 0.211 & 0.239 & $*$ & 0.204 & 0.172 & 0.244 & $*$ \\
\hline Inc between $\$ 20352$ and $\$ 500909$ & 0.242 & 0.259 & 0.202 & * & 0.148 & 0.113 & 0.19 & * \\
\hline Income missing & 0.045 & 0.049 & 0.037 & * & 0.036 & 0.044 & 0.026 & \\
\hline Gambled & 0.646 & 0.639 & 0.663 & * & 0.519 & 0.454 & 0.599 & \\
\hline Has savings account & 0.628 & 0.668 & 0.533 & $*$ & 0.649 & 0.702 & 0.542 & $*$ \\
\hline Lottery & 0.637 & 0.625 & 0.667 & * & 0.586 & 0.521 & 0.666 & $*$ \\
\hline \multirow[t]{2}{*}{ Propensity to take risks } & 2.8 & 2.75 & 2.92 & $*$ & 2.323 & 2.341 & 2.301 & $*$ \\
\hline & $(0.91)$ & $(0.92)$ & $(0.88)$ & & $(0.87)$ & $(0.89)$ & $(0.83)$ & \\
\hline \multirow[t]{2}{*}{ Age } & 22.022 & 21.971 & 22.143 & $*$ & 21.819 & 21.545 & 22.158 & $*$ \\
\hline & $(1.75)$ & $(1.77)$ & $(1.71)$ & & $(1.76)$ & $(1.81)$ & $(1.63)$ & \\
\hline Religious & 1.311 & 1.339 & 1.245 & * & 1.47 & 1.478 & 1.461 & $*$ \\
\hline White & 0.671 & 0.668 & 0.672 & & 0.657 & 0.657 & 0.658 & \\
\hline Black & 0.208 & 0.221 & 0.202 & & 0.24 & 0.24 & 0.24 & \\
\hline Other race & 0.122 & 0.111 & 0.126 & & 0.102 & 0.103 & 0.102 & \\
\hline Hispanic & 0.156 & 0.147 & 0.161 & $*$ & 0.142 & 0.159 & 0.128 & \\
\hline
\end{tabular}




\begin{tabular}{|c|c|c|c|c|c|c|c|c|}
\hline Wave 1 variables & All men & Trouble paying bills & No trouble paying bills & Sig $^{\mathrm{a}}$ & All women & Trouble paying bills & No trouble paying bills & $\operatorname{Sig}^{\mathrm{a}}$ \\
\hline Drank in past 30 days & 0.11 & 0.105 & 0.121 & $*$ & 0.071 & 0.072 & 0.069 & $*$ \\
\hline Thinks smart compared to others & 0.566 & 0.578 & 0.535 & $*$ & 0.556 & 0.523 & 0.597 & * \\
\hline Likely to go to college & 0.495 & 0.529 & 0.414 & * & 0.623 & 0.6 & 0.653 & * \\
\hline Usual hours of work in summer & 16.479 & 16.161 & 17.236 & $*$ & 13.041 & 11.242 & 15.268 & $*$ \\
\hline Dad had management/professional job & 0.173 & 0.185 & 0.147 & * & 0.167 & 0.172 & 0.161 & * \\
\hline Dad did not work & 0.04 & 0.035 & 0.052 & $*$ & 0.035 & 0.038 & 0.032 & * \\
\hline Dad's job unknown & 0.259 & 0.239 & 0.306 & $*$ & 0.298 & 0.301 & 0.293 & * \\
\hline Dad's job other than management/professional & 0.528 & 0.541 & 0.496 & * & 0.5 & 0.489 & 0.514 & * \\
\hline Smoked in high school & 0.187 & 0.16 & 0.252 & $*$ & 0.188 & 0.184 & 0.191 & * \\
\hline Highest level of parent's education is college & 0.396 & 0.415 & 0.351 & * & 0.367 & 0.363 & 0.372 & * \\
\hline Highest level of parent's education is some college & 0.201 & 0.2 & 0.205 & & 0.217 & 0.195 & 0.245 & \\
\hline Highest level of parent's education is HS diploma & 0.275 & 0.265 & 0.301 & * & 0.282 & 0.288 & 0.273 & * \\
\hline Highest level of parent's education is less than HS & 0.095 & 0.091 & 0.105 & * & 0.107 & 0.116 & 0.095 & * \\
\hline Highest level of parental education is unknown & 0.032 & 0.029 & 0.038 & $*$ & 0.027 & 0.037 & 0.015 & \\
\hline Parent received welfare & 0.096 & 0.078 & 0.138 & $*$ & 0.102 & 0.12 & 0.08 & * \\
\hline Parent smoked & 0.23 & 0.213 & 0.27 & $*$ & 0.245 & 0.253 & 0.235 & * \\
\hline Mom obese & 0.153 & 0.15 & 0.158 & & 0.158 & 0.152 & 0.165 & * \\
\hline Mom was a binge drinker & 0.104 & 0.099 & 0.117 & $*$ & 0.105 & 0.107 & 0.102 & * \\
\hline Mom's binge drinking unknown & 0.135 & 0.135 & 0.135 & & 0.142 & 0.14 & 0.144 & * \\
\hline Mom breastfed & 0.368 & 0.378 & 0.344 & $*$ & 0.361 & 0.358 & 0.364 & $*$ \\
\hline Unknown if mom breastfed & 0.164 & 0.164 & 0.164 & & 0.157 & 0.155 & 0.159 & * \\
\hline \multirow[t]{2}{*}{ High school GPA } & 2.677 & 2.726 & 2.56 & $*$ & 2.895 & 2.872 & 2.923 & * \\
\hline & $(0.77)$ & $(0.77)$ & $(0.77)$ & & $(0.75)$ & $(0.78)$ & $(0.71)$ & \\
\hline Took something from a store without paying for it & 0.277 & 0.254 & 0.333 & * & 0.212 & 0.207 & 0.219 & * \\
\hline $\mathrm{N}$ & 6,442 & 4,540 & 1,902 & & 7,157 & 3,958 & 3,199 & \\
\hline
\end{tabular}

Note: Income is total personal before tax income measured in \$.

${ }^{a}$ indicates significant at the $10 \%$ level 
Table 3a: OLS Models of the Effect of Having Credit Card Debt on Body Weight

\begin{tabular}{|c|c|c|c|c|c|c|}
\hline \multirow[b]{2}{*}{ VARIABLES } & \multicolumn{3}{|c|}{ Men } & \multicolumn{3}{|c|}{ Women } \\
\hline & BMI & $\begin{array}{c}\text { Overweight/ } \\
\text { obese }\end{array}$ & Obese & BMI & $\begin{array}{c}\text { Overweight/ } \\
\text { Obese }\end{array}$ & Obese \\
\hline \multicolumn{7}{|l|}{ Wave III Variables } \\
\hline Has credit card debt & $\begin{array}{c}0.135 \\
(0.136)\end{array}$ & $\begin{array}{c}0.026 * * \\
(0.013)\end{array}$ & $\begin{array}{c}0.006 \\
(0.010)\end{array}$ & $\begin{array}{c}0.355^{* *} \\
(0.148)\end{array}$ & $\begin{array}{l}0.020^{*} \\
(0.012)\end{array}$ & $\begin{array}{c}0.013 \\
(0.009)\end{array}$ \\
\hline Volunteer & & & & $\begin{array}{c}0.700^{* * *} \\
(0.169)\end{array}$ & $\begin{array}{c}0.030 * * \\
(0.013)\end{array}$ & $\begin{array}{c}0.033^{* * * *} \\
(0.010)\end{array}$ \\
\hline Age & $\begin{array}{c}-0.583 \\
(0.866)\end{array}$ & $\begin{array}{c}-0.070 \\
(0.078)\end{array}$ & $\begin{array}{c}-0.110 * \\
(0.063)\end{array}$ & $\begin{array}{l}1.821^{*} \\
(0.989)\end{array}$ & $\begin{array}{c}0.116 \\
(0.075)\end{array}$ & $\begin{array}{c}0.155^{* *} \\
(0.061)\end{array}$ \\
\hline Age squared & $\begin{array}{c}0.018 \\
(0.020)\end{array}$ & $\begin{array}{c}0.002 \\
(0.002)\end{array}$ & $\begin{array}{l}0.003 * \\
(0.001)\end{array}$ & $\begin{array}{c}-0.038 * \\
(0.023)\end{array}$ & $\begin{array}{l}-0.002 \\
(0.002)\end{array}$ & $\begin{array}{c}-0.003^{* *} \\
(0.001)\end{array}$ \\
\hline Married & $\begin{array}{c}0.598 * * * \\
(0.198)\end{array}$ & $\begin{array}{c}0.056 * * * \\
(0.018)\end{array}$ & $\begin{array}{c}0.033 * * \\
(0.015)\end{array}$ & $\begin{array}{c}0.972 * * * \\
(0.191)\end{array}$ & $\begin{array}{c}0.101^{* * *} \\
(0.015)\end{array}$ & $\begin{array}{c}0.044^{* * *} \\
(0.013)\end{array}$ \\
\hline Inc. btw \$1 -\$7 & $\begin{array}{c}0.325 \\
(0.337)\end{array}$ & $\begin{array}{c}0.020 \\
(0.033)\end{array}$ & $\begin{array}{c}0.032 \\
(0.025)\end{array}$ & $\begin{array}{c}0.590 \\
(0.411)\end{array}$ & $\begin{array}{c}0.044 \\
(0.031)\end{array}$ & $\begin{array}{c}0.039 \\
(0.025)\end{array}$ \\
\hline Inc. btw $\$ 8-\$ 3900$ & $\begin{array}{c}0.101 \\
(0.332)\end{array}$ & $\begin{array}{l}-0.020 \\
(0.033)\end{array}$ & $\begin{array}{c}0.018 \\
(0.025)\end{array}$ & $\begin{array}{c}1.117 * * * \\
(0.414)\end{array}$ & $\begin{array}{c}0.091 * * * \\
(0.031)\end{array}$ & $\begin{array}{l}0.057 * * \\
(0.025)\end{array}$ \\
\hline Inc. btw $\$ 4000-\$ 11700$ & $\begin{array}{c}-0.147 \\
(0.331)\end{array}$ & $\begin{array}{l}-0.045 \\
(0.033)\end{array}$ & $\begin{array}{c}0.022 \\
(0.025)\end{array}$ & $\begin{array}{c}0.937 * * \\
(0.417)\end{array}$ & $\begin{array}{c}0.071^{* *} \\
(0.032)\end{array}$ & $\begin{array}{c}0.053 * * \\
(0.026)\end{array}$ \\
\hline Inc. btw \$12000-\$20100 & $\begin{array}{c}0.115 \\
(0.321)\end{array}$ & $\begin{array}{l}-0.011 \\
(0.032)\end{array}$ & $\begin{array}{c}0.007 \\
(0.024)\end{array}$ & $\begin{array}{c}1.083^{* * * *} \\
(0.415)\end{array}$ & $\begin{array}{c}0.087 * * * \\
(0.031)\end{array}$ & $\begin{array}{c}0.059 * * \\
(0.026)\end{array}$ \\
\hline Income missing & $\begin{array}{c}0.142 \\
(0.319)\end{array}$ & $\begin{array}{c}0.012 \\
(0.032)\end{array}$ & $\begin{array}{c}0.017 \\
(0.025)\end{array}$ & $\begin{array}{c}0.630 \\
(0.424)\end{array}$ & $\begin{array}{c}0.042 \\
(0.033)\end{array}$ & $\begin{array}{l}0.043 * \\
(0.026)\end{array}$ \\
\hline Gamble & $\begin{array}{c}0.204 \\
(0.151)\end{array}$ & $\begin{array}{c}0.014 \\
(0.014)\end{array}$ & $\begin{array}{c}-0.011 \\
(0.011)\end{array}$ & $\begin{array}{l}0.298 * \\
(0.158)\end{array}$ & $\begin{array}{c}-0.004 \\
(0.013)\end{array}$ & $\begin{array}{c}0.004 \\
(0.010)\end{array}$ \\
\hline Has savings account & $\begin{array}{c}0.092 \\
(0.138)\end{array}$ & $\begin{array}{l}0.022 * \\
(0.013)\end{array}$ & $\begin{array}{c}-0.013 \\
(0.010)\end{array}$ & $\begin{array}{c}-0.735^{* * *} \\
(0.161)\end{array}$ & $\begin{array}{c}-0.049 * * * \\
(0.012)\end{array}$ & $\begin{array}{c}-0.032 * * * \\
(0.010)\end{array}$ \\
\hline Lottery & $\begin{array}{c}0.559 * * * \\
(0.146)\end{array}$ & $\begin{array}{c}0.039 * * * \\
(0.014)\end{array}$ & $\begin{array}{c}0.044^{* * *} \\
(0.011)\end{array}$ & $\begin{array}{c}0.148 \\
(0.159)\end{array}$ & $\begin{array}{c}0.037 * * * \\
(0.013)\end{array}$ & $\begin{array}{c}0.004 \\
(0.010)\end{array}$ \\
\hline Propensity to take risks & $\begin{array}{c}0.039 \\
(0.071)\end{array}$ & $\begin{array}{c}-0.002 \\
(0.007)\end{array}$ & $\begin{array}{c}0.004 \\
(0.005)\end{array}$ & $\begin{array}{l}0.178 * * \\
(0.088)\end{array}$ & $\begin{array}{c}0.010 \\
(0.007)\end{array}$ & $\begin{array}{c}0.004 \\
(0.006)\end{array}$ \\
\hline Religious & $\begin{array}{c}0.234^{* * *} \\
(0.070)\end{array}$ & $\begin{array}{c}0.024^{* * *} \\
(0.007)\end{array}$ & $\begin{array}{c}0.014^{* * *} \\
(0.005)\end{array}$ & $\begin{array}{c}0.224^{* * *} \\
(0.082)\end{array}$ & $\begin{array}{c}0.013 * * \\
(0.006)\end{array}$ & $\begin{array}{l}0.009 * \\
(0.005)\end{array}$ \\
\hline Black & $\begin{array}{c}0.443 * * \\
(0.188)\end{array}$ & $\begin{array}{c}0.008 \\
(0.018)\end{array}$ & $\begin{array}{c}0.032 * * \\
(0.014)\end{array}$ & $\begin{array}{c}1.609 * * * \\
(0.209)\end{array}$ & $\begin{array}{c}0.138 * * * \\
(0.016)\end{array}$ & $\begin{array}{c}0.058 * * * \\
(0.013)\end{array}$ \\
\hline Other race & $\begin{array}{c}0.716^{* * *} \\
(0.221)\end{array}$ & $\begin{array}{c}0.040 * * \\
(0.020)\end{array}$ & $\begin{array}{c}0.048 * * * \\
(0.016)\end{array}$ & $\begin{array}{c}-0.442 * \\
(0.239)\end{array}$ & $\begin{array}{c}-0.038 * * \\
(0.018)\end{array}$ & $\begin{array}{c}-0.016 \\
(0.015)\end{array}$ \\
\hline Hispanic & $\begin{array}{c}0.954^{* * *} \\
(0.193)\end{array}$ & $\begin{array}{c}0.085^{* * *} \\
(0.018)\end{array}$ & $\begin{array}{c}0.037 * * \\
(0.015)\end{array}$ & $\begin{array}{c}0.593 * * * \\
(0.224)\end{array}$ & $\begin{array}{c}0.065 * * * \\
(0.018)\end{array}$ & $\begin{array}{c}0.023 \\
(0.015)\end{array}$ \\
\hline$\underline{\text { Wave I Variables }}$ & & & & & & \\
\hline Drank in past 30 days & $\begin{array}{c}0.269 \\
(0.203)\end{array}$ & $\begin{array}{c}0.044 * * \\
(0.020)\end{array}$ & $\begin{array}{c}0.014 \\
(0.017)\end{array}$ & $\begin{array}{l}-0.455 \\
(0.288)\end{array}$ & $\begin{array}{l}-0.020 \\
(0.023)\end{array}$ & $\begin{array}{l}-0.024 \\
(0.018)\end{array}$ \\
\hline Thinks smart compared to others & $\begin{array}{c}0.104 \\
(0.142)\end{array}$ & $\begin{array}{c}0.008 \\
(0.014)\end{array}$ & $\begin{array}{c}0.003 \\
(0.011)\end{array}$ & $\begin{array}{c}0.252 \\
(0.162)\end{array}$ & $\begin{array}{c}0.005 \\
(0.013)\end{array}$ & $\begin{array}{l}0.017 * \\
(0.010)\end{array}$ \\
\hline Likely to go to college & $\begin{array}{c}0.029 \\
(0.142)\end{array}$ & $\begin{array}{c}0.009 \\
(0.014)\end{array}$ & $\begin{array}{l}-0.002 \\
(0.011)\end{array}$ & $\begin{array}{l}-0.250 \\
(0.169)\end{array}$ & $\begin{array}{l}-0.012 \\
(0.013)\end{array}$ & $\begin{array}{l}-0.019 * \\
(0.011)\end{array}$ \\
\hline Usual summer work hrs & 0.003 & 0.000 & 0.000 & -0.007 & -0.000 & -0.000 \\
\hline
\end{tabular}




\begin{tabular}{|c|c|c|c|c|c|c|}
\hline & $(0.004)$ & $(0.000)$ & $(0.000)$ & $(0.005)$ & $(0.000)$ & $(0.000)$ \\
\hline \multirow[t]{2}{*}{ Dad unemployed } & 0.405 & 0.054 & 0.022 & $0.870 *$ & $0.118 * * *$ & 0.039 \\
\hline & $(0.376)$ & $(0.035)$ & $(0.028)$ & $(0.461)$ & $(0.034)$ & $(0.030)$ \\
\hline \multirow[t]{2}{*}{ Dad job unknown } & 0.053 & -0.012 & 0.012 & $0.513 * *$ & $0.076 * * *$ & 0.022 \\
\hline & $(0.216)$ & $(0.021)$ & $(0.016)$ & $(0.232)$ & $(0.018)$ & $(0.014)$ \\
\hline \multirow[t]{2}{*}{ Dad job other than manag/prof } & 0.198 & 0.023 & 0.019 & $0.362 *$ & $0.059 * * *$ & 0.008 \\
\hline & $(0.177)$ & $(0.018)$ & $(0.013)$ & $(0.193)$ & $(0.016)$ & $(0.012)$ \\
\hline \multirow[t]{2}{*}{ Smoked in HS } & $-0.541 * * *$ & $-0.038 * *$ & -0.012 & -0.333 & -0.011 & -0.021 \\
\hline & $(0.176)$ & $(0.017)$ & $(0.013)$ & $(0.210)$ & $(0.016)$ & $(0.014)$ \\
\hline \multirow[t]{2}{*}{ Parent has some college } & 0.161 & 0.024 & 0.004 & 0.222 & $0.029 *$ & 0.003 \\
\hline & $(0.178)$ & $(0.017)$ & $(0.014)$ & $(0.201)$ & $(0.016)$ & $(0.013)$ \\
\hline \multirow[t]{2}{*}{ Parent educ. HS graduate } & 0.216 & 0.020 & 0.004 & $0.696 * * *$ & $0.074 * * *$ & $0.040 * * *$ \\
\hline & $(0.183)$ & $(0.017)$ & $(0.013)$ & $(0.201)$ & $(0.016)$ & $(0.013)$ \\
\hline \multirow[t]{2}{*}{ Parent educ. less than HS } & 0.095 & 0.037 & 0.005 & $0.881^{* * *}$ & $0.056 * *$ & $0.060 * * *$ \\
\hline & $(0.261)$ & $(0.025)$ & $(0.020)$ & $(0.298)$ & $(0.023)$ & $(0.019)$ \\
\hline \multirow[t]{2}{*}{ Parent educ. unknown } & 0.273 & 0.022 & 0.035 & -0.071 & 0.019 & 0.021 \\
\hline & $(0.404)$ & $(0.037)$ & $(0.030)$ & $(0.462)$ & $(0.037)$ & $(0.031)$ \\
\hline \multirow[t]{2}{*}{ Parent on welfare } & -0.256 & -0.022 & $-0.037 * *$ & $0.782 * * *$ & 0.026 & $0.050 * * *$ \\
\hline & $(0.243)$ & $(0.022)$ & $(0.017)$ & $(0.293)$ & $(0.020)$ & $(0.018)$ \\
\hline \multirow[t]{2}{*}{ Parent smoked } & $0.390 * *$ & 0.017 & $0.028 * *$ & $0.937 * * *$ & $0.063 * * *$ & $0.050 * * *$ \\
\hline & $(0.171)$ & $(0.016)$ & $(0.012)$ & $(0.186)$ & $(0.014)$ & $(0.012)$ \\
\hline \multirow[t]{2}{*}{ Mom obese } & $3.082 * * *$ & $0.184^{* * *}$ & $0.187 * * *$ & $3.707 * * *$ & $0.212 * * *$ & $0.194 * * *$ \\
\hline & $(0.217)$ & $(0.017)$ & $(0.016)$ & $(0.239)$ & $(0.016)$ & $(0.015)$ \\
\hline \multirow[t]{2}{*}{ Mom binge drank } & -0.319 & -0.023 & $-0.028 *$ & 0.131 & -0.004 & 0.007 \\
\hline & $(0.210)$ & $(0.021)$ & $(0.015)$ & $(0.251)$ & $(0.019)$ & $(0.016)$ \\
\hline \multirow[t]{2}{*}{ Mom binge not known } & 0.123 & 0.003 & -0.005 & $0.672 *$ & 0.042 & 0.012 \\
\hline & $(0.299)$ & $(0.028)$ & $(0.022)$ & $(0.358)$ & $(0.026)$ & $(0.023)$ \\
\hline \multirow[t]{2}{*}{ Mom breast fed } & $-0.404 * * *$ & $-0.046 * * *$ & $-0.025 * *$ & $-0.456 * * *$ & -0.018 & $-0.035 * * *$ \\
\hline & $(0.146)$ & $(0.014)$ & $(0.011)$ & $(0.160)$ & $(0.013)$ & $(0.010)$ \\
\hline \multirow[t]{2}{*}{ Mom breast fed unknown } & -0.013 & 0.006 & 0.015 & 0.355 & 0.010 & $0.044 * *$ \\
\hline & $(0.278)$ & $(0.027)$ & $(0.021)$ & $(0.344)$ & $(0.025)$ & $(0.022)$ \\
\hline \multirow[t]{2}{*}{ GPA } & $-0.290 * * *$ & $-0.025 * * *$ & $-0.019 * *$ & $-0.809 * * *$ & $-0.050 * * *$ & $-0.045 * * *$ \\
\hline & $(0.099)$ & $(0.009)$ & $(0.007)$ & $(0.120)$ & $(0.009)$ & $(0.008)$ \\
\hline \multirow[t]{2}{*}{ Took something from store w/o paying for it } & $-0.346^{* *}$ & -0.020 & $-0.018 *$ & $-0.335^{*}$ & $-0.040 * * *$ & -0.017 \\
\hline & $(0.142)$ & $(0.014)$ & $(0.011)$ & (0.186) & $(0.014)$ & $(0.011)$ \\
\hline \multirow[t]{2}{*}{ Constant } & $28.716 * * *$ & 1.013 & $1.223^{*}$ & 2.608 & -1.107 & $-1.595 * *$ \\
\hline & (9.536) & $(0.860)$ & $(0.686)$ & (10.668) & $(0.816)$ & $(0.655)$ \\
\hline Observations & 6,442 & 6,442 & 6,442 & 7,157 & 7,157 & 7,157 \\
\hline R-squared & 0.077 & 0.054 & 0.048 & 0.122 & 0.102 & 0.083 \\
\hline
\end{tabular}

Robust standard errors in parentheses. ${ }^{* * *} \mathrm{p}<0.01,{ }^{* *} \mathrm{p}<0.05,{ }^{*} \mathrm{p}<0.1$. Benchmark categories: father's job is managerial/professional, income is unknown, parent's highest level of education is college or more. 
Table 3b: OLS Models of the Effect of Having Trouble Paying Bills on Body Weight

\begin{tabular}{|c|c|c|c|c|c|c|}
\hline \multirow{2}{*}{ VARIABLES } & \multicolumn{3}{|c|}{ Men } & \multicolumn{3}{|c|}{ Women } \\
\hline & BMI & $\begin{array}{c}\text { Overweight/ } \\
\text { obese }\end{array}$ & Obese & BMI & $\begin{array}{c}\text { Overweight/ } \\
\text { Obese }\end{array}$ & Obese \\
\hline \multicolumn{7}{|l|}{ Wave III Variables } \\
\hline Has trouble paying bills & $\begin{array}{c}-0.103 \\
(0.150)\end{array}$ & $\begin{array}{c}-0.041^{* * *} \\
(0.014)\end{array}$ & $\begin{array}{l}-0.003 \\
(0.011)\end{array}$ & $\begin{array}{c}0.727 * * * \\
(0.161)\end{array}$ & $\begin{array}{c}0.047 * * * \\
(0.013)\end{array}$ & $\begin{array}{c}0.040^{* * *} \\
(0.011)\end{array}$ \\
\hline Volunteer & & & & $\begin{array}{c}0.715^{* * *} \\
(0.169)\end{array}$ & $\begin{array}{c}0.032 * * \\
(0.013)\end{array}$ & $\begin{array}{c}0.034^{* * *} \\
(0.010)\end{array}$ \\
\hline Has a credit card & $\begin{array}{c}0.161 \\
(0.147)\end{array}$ & $\begin{array}{c}0.032 * * \\
(0.014)\end{array}$ & $\begin{array}{l}-0.004 \\
(0.011)\end{array}$ & $\begin{array}{c}-0.567 * * * \\
(0.167)\end{array}$ & $\begin{array}{c}-0.055^{* * * *} \\
(0.013)\end{array}$ & $\begin{array}{c}-0.034^{* * * *} \\
(0.011)\end{array}$ \\
\hline Age & $\begin{array}{l}-0.582 \\
(0.865)\end{array}$ & $\begin{array}{l}-0.069 \\
(0.078)\end{array}$ & $\begin{array}{l}-0.105^{*} \\
(0.063)\end{array}$ & $\begin{array}{c}2.064 * * \\
(0.981)\end{array}$ & $\begin{array}{l}0.135^{*} \\
(0.075)\end{array}$ & $\begin{array}{c}0.166^{* * *} \\
(0.060)\end{array}$ \\
\hline Age squared & $\begin{array}{c}0.018 \\
(0.020)\end{array}$ & $\begin{array}{c}0.002 \\
(0.002)\end{array}$ & $\begin{array}{l}0.003^{*} \\
(0.001)\end{array}$ & $\begin{array}{c}-0.043^{*} \\
(0.023)\end{array}$ & $\begin{array}{l}-0.003 \\
(0.002)\end{array}$ & $\begin{array}{c}-0.004^{* * * *} \\
(0.001)\end{array}$ \\
\hline Married & $\begin{array}{c}0.611^{* * *} \\
(0.197)\end{array}$ & $\begin{array}{c}0.059 * * * \\
(0.018)\end{array}$ & $\begin{array}{c}0.034^{* * *} \\
(0.015)\end{array}$ & $\begin{array}{c}0.966^{* * *} \\
(0.190)\end{array}$ & $\begin{array}{c}0.100^{* * *} \\
(0.015)\end{array}$ & $\begin{array}{c}0.043^{* * *} \\
(0.013)\end{array}$ \\
\hline Inc. btw $\$ 1-\$ 7$ & $\begin{array}{c}0.356 \\
(0.338)\end{array}$ & $\begin{array}{c}0.028 \\
(0.033)\end{array}$ & $\begin{array}{c}0.032 \\
(0.025)\end{array}$ & $\begin{array}{c}0.548 \\
(0.413)\end{array}$ & $\begin{array}{c}0.040 \\
(0.031)\end{array}$ & $\begin{array}{c}0.036 \\
(0.025)\end{array}$ \\
\hline Inc. btw $\$ 8-\$ 3900$ & $\begin{array}{c}0.122 \\
(0.332)\end{array}$ & $\begin{array}{l}-0.014 \\
(0.033)\end{array}$ & $\begin{array}{c}0.018 \\
(0.025)\end{array}$ & $\begin{array}{c}1.104^{* * * *} \\
(0.416)\end{array}$ & $\begin{array}{c}0.090 * * * \\
(0.031)\end{array}$ & $\begin{array}{c}0.056 * * \\
(0.025)\end{array}$ \\
\hline Inc. btw $\$ 4000-\$ 11700$ & $\begin{array}{l}-0.118 \\
(0.331)\end{array}$ & $\begin{array}{l}-0.038 \\
(0.033)\end{array}$ & $\begin{array}{c}0.023 \\
(0.025)\end{array}$ & $\begin{array}{c}0.911 * * \\
(0.419)\end{array}$ & $\begin{array}{c}0.069 * * \\
(0.032)\end{array}$ & $\begin{array}{c}0.051^{* *} \\
(0.026)\end{array}$ \\
\hline Inc. btw $\$ 12000-\$ 20100$ & $\begin{array}{c}0.142 \\
(0.321)\end{array}$ & $\begin{array}{l}-0.004 \\
(0.032)\end{array}$ & $\begin{array}{c}0.008 \\
(0.024)\end{array}$ & $\begin{array}{c}1.137 * * * \\
(0.417)\end{array}$ & $\begin{array}{c}0.091 * * * \\
(0.032)\end{array}$ & $\begin{array}{c}0.061^{* *} \\
(0.026)\end{array}$ \\
\hline Income missing & $\begin{array}{c}0.144 \\
(0.319)\end{array}$ & $\begin{array}{c}0.012 \\
(0.032)\end{array}$ & $\begin{array}{c}0.018 \\
(0.025)\end{array}$ & $\begin{array}{l}0.783^{*} \\
(0.426)\end{array}$ & $\begin{array}{l}0.054^{*} \\
(0.033)\end{array}$ & $\begin{array}{l}0.051^{*} \\
(0.026)\end{array}$ \\
\hline Gamble & $\begin{array}{c}0.202 \\
(0.150)\end{array}$ & $\begin{array}{c}0.014 \\
(0.014)\end{array}$ & $\begin{array}{l}-0.011 \\
(0.011)\end{array}$ & $\begin{array}{c}0.359 * * \\
(0.158)\end{array}$ & $\begin{array}{c}0.000 \\
(0.013)\end{array}$ & $\begin{array}{c}0.007 \\
(0.010)\end{array}$ \\
\hline Has savings account & $\begin{array}{c}0.059 \\
(0.142)\end{array}$ & $\begin{array}{c}0.014 \\
(0.013)\end{array}$ & $\begin{array}{l}-0.012 \\
(0.011)\end{array}$ & $\begin{array}{c}-0.561^{* * *} \\
(0.162)\end{array}$ & $\begin{array}{c}-0.035^{* * *} \\
(0.012)\end{array}$ & $\begin{array}{c}-0.022^{* *} \\
(0.010)\end{array}$ \\
\hline Lottery & $\begin{array}{c}0.568 * * * \\
(0.145)\end{array}$ & $\begin{array}{c}0.041^{* * * *} \\
(0.014)\end{array}$ & $\begin{array}{c}0.044^{* * * *} \\
(0.011)\end{array}$ & $\begin{array}{c}0.179 \\
(0.158)\end{array}$ & $\begin{array}{c}0.039 * * * \\
(0.013)\end{array}$ & $\begin{array}{c}0.005 \\
(0.010)\end{array}$ \\
\hline Propensity to take risks & $\begin{array}{c}0.047 \\
(0.072)\end{array}$ & $\begin{array}{c}0.000 \\
(0.007)\end{array}$ & $\begin{array}{c}0.004 \\
(0.005)\end{array}$ & $\begin{array}{c}0.122 \\
(0.088)\end{array}$ & $\begin{array}{c}0.005 \\
(0.007)\end{array}$ & $\begin{array}{c}0.001 \\
(0.006)\end{array}$ \\
\hline Religious & $\begin{array}{c}0.232 * * * \\
(0.070)\end{array}$ & $\begin{array}{c}0.023^{* * * *} \\
(0.007)\end{array}$ & $\begin{array}{c}0.014^{* * *} \\
(0.005)\end{array}$ & $\begin{array}{c}0.225 * * * \\
(0.081)\end{array}$ & $\begin{array}{c}0.013^{* *} \\
(0.006)\end{array}$ & $\begin{array}{l}0.009 * \\
(0.005)\end{array}$ \\
\hline Black & $\begin{array}{c}0.460^{* * *} \\
(0.189)\end{array}$ & $\begin{array}{c}0.011 \\
(0.018)\end{array}$ & $\begin{array}{c}0.031^{* *} \\
(0.014)\end{array}$ & $\begin{array}{c}1.557 * * * * \\
(0.210)\end{array}$ & $\begin{array}{c}0.133^{* * *} \\
(0.016)\end{array}$ & $\begin{array}{c}0.055^{* * *} \\
(0.013)\end{array}$ \\
\hline Other race & $\begin{array}{c}0.705^{* * *} \\
(0.221)\end{array}$ & $\begin{array}{l}0.038^{*} \\
(0.020)\end{array}$ & $\begin{array}{c}0.048^{* * * *} \\
(0.016)\end{array}$ & $\begin{array}{c}-0.408^{*} \\
(0.237)\end{array}$ & $\begin{array}{c}-0.035^{*} \\
(0.018)\end{array}$ & $\begin{array}{l}-0.014 \\
(0.014)\end{array}$ \\
\hline Hispanic & $\begin{array}{c}0.951 * * * \\
(0.192)\end{array}$ & $\begin{array}{c}0.084^{* * * *} \\
(0.018)\end{array}$ & $\begin{array}{c}0.038 * * \\
(0.015)\end{array}$ & $\begin{array}{c}0.667 * * * \\
(0.223)\end{array}$ & $\begin{array}{c}0.070^{* * * *} \\
(0.018)\end{array}$ & $\begin{array}{l}0.027^{*} \\
(0.015)\end{array}$ \\
\hline \multicolumn{7}{|l|}{ Wave I Variables } \\
\hline Drank in past 30 days & $\begin{array}{c}0.262 \\
(0.203)\end{array}$ & $\begin{array}{c}0.042 * * \\
(0.020)\end{array}$ & $\begin{array}{c}0.014 \\
(0.017)\end{array}$ & $\begin{array}{l}-0.462 \\
(0.285)\end{array}$ & $\begin{array}{l}-0.021 \\
(0.023)\end{array}$ & $\begin{array}{l}-0.024 \\
(0.018)\end{array}$ \\
\hline Thinks smart compared to others & $\begin{array}{c}0.105 \\
(0.142)\end{array}$ & $\begin{array}{c}0.009 \\
(0.014)\end{array}$ & $\begin{array}{c}0.003 \\
(0.011)\end{array}$ & $\begin{array}{l}0.281^{*} \\
(0.162)\end{array}$ & $\begin{array}{c}0.008 \\
(0.013)\end{array}$ & $\begin{array}{l}0.019 * \\
(0.010)\end{array}$ \\
\hline
\end{tabular}




\begin{tabular}{|c|c|c|c|c|c|c|}
\hline Likely to go to college & $\begin{array}{c}0.015 \\
(0.143)\end{array}$ & $\begin{array}{c}0.005 \\
(0.014)\end{array}$ & $\begin{array}{c}-0.002 \\
(0.011)\end{array}$ & $\begin{array}{c}-0.167 \\
(0.170)\end{array}$ & $\begin{array}{c}-0.005 \\
(0.013)\end{array}$ & $\begin{array}{c}-0.015 \\
(0.011)\end{array}$ \\
\hline \multirow[t]{2}{*}{ Usual summer work hrs } & 0.003 & 0.000 & 0.000 & -0.007 & -0.000 & -0.000 \\
\hline & $(0.004)$ & $(0.000)$ & $(0.000)$ & $(0.005)$ & $(0.000)$ & $(0.000)$ \\
\hline \multirow[t]{2}{*}{ Dad unemployed } & 0.422 & 0.058 & 0.023 & $0.799 *$ & $0.113^{* * *}$ & 0.035 \\
\hline & $(0.376)$ & $(0.035)$ & $(0.028)$ & $(0.461)$ & $(0.034)$ & $(0.030)$ \\
\hline \multirow[t]{2}{*}{ Dad job unknown } & 0.071 & -0.008 & 0.012 & $0.449 *$ & $0.071 * * *$ & 0.018 \\
\hline & $(0.216)$ & $(0.021)$ & $(0.016)$ & $(0.232)$ & $(0.018)$ & $(0.014)$ \\
\hline \multirow[t]{2}{*}{ Dad job other than manag/prof } & 0.205 & 0.024 & 0.019 & $0.350 *$ & $0.058 * * *$ & 0.008 \\
\hline & $(0.177)$ & $(0.018)$ & $(0.013)$ & $(0.193)$ & $(0.016)$ & $(0.012)$ \\
\hline \multirow[t]{2}{*}{ Smoked in HS } & $-0.527 * * *$ & $-0.033^{*}$ & -0.012 & $-0.438 * *$ & -0.018 & $-0.027 * *$ \\
\hline & $(0.177)$ & $(0.017)$ & $(0.014)$ & $(0.210)$ & $(0.016)$ & $(0.014)$ \\
\hline \multirow[t]{2}{*}{ Parent has some college } & 0.169 & 0.026 & 0.004 & 0.221 & $0.029 *$ & 0.003 \\
\hline & $(0.178)$ & $(0.017)$ & $(0.014)$ & $(0.201)$ & $(0.016)$ & $(0.013)$ \\
\hline \multirow[t]{2}{*}{ Parent educ. HS graduate } & 0.220 & 0.021 & 0.003 & $0.651^{* * *}$ & $0.070 * * *$ & $0.037 * * *$ \\
\hline & $(0.183)$ & $(0.017)$ & $(0.013)$ & $(0.200)$ & $(0.016)$ & $(0.013)$ \\
\hline \multirow[t]{2}{*}{ Parent educ. less than HS } & 0.103 & 0.039 & 0.004 & $0.775 * * *$ & $0.047 * *$ & $0.054 * * *$ \\
\hline & $(0.261)$ & $(0.025)$ & $(0.020)$ & $(0.296)$ & $(0.023)$ & $(0.019)$ \\
\hline \multirow[t]{2}{*}{ Parent educ. unknown } & 0.277 & 0.024 & 0.035 & -0.188 & 0.010 & 0.015 \\
\hline & $(0.404)$ & $(0.037)$ & $(0.030)$ & $(0.458)$ & $(0.037)$ & $(0.031)$ \\
\hline \multirow[t]{2}{*}{ Parent on welfare } & -0.248 & -0.019 & $-0.037 * *$ & $0.672 * *$ & 0.018 & $0.044 * *$ \\
\hline & $(0.243)$ & $(0.022)$ & $(0.017)$ & $(0.292)$ & $(0.020)$ & $(0.018)$ \\
\hline \multirow[t]{2}{*}{ Parent smoked } & $0.396 * *$ & 0.018 & $0.028 * *$ & $0.872 * * *$ & $0.059 * * *$ & $0.047 * * *$ \\
\hline & $(0.171)$ & $(0.016)$ & $(0.012)$ & $(0.185)$ & $(0.015)$ & $(0.012)$ \\
\hline \multirow[t]{2}{*}{ Mom obese } & $3.086 * * *$ & $0.185^{* * *}$ & $0.187 * * *$ & $3.683 * * *$ & $0.210 * * *$ & $0.193 * * *$ \\
\hline & $(0.217)$ & $(0.017)$ & $(0.016)$ & $(0.239)$ & $(0.016)$ & $(0.015)$ \\
\hline \multirow[t]{2}{*}{ Mom binge drank } & -0.318 & -0.022 & $-0.028 *$ & 0.111 & -0.006 & 0.006 \\
\hline & $(0.210)$ & $(0.021)$ & $(0.015)$ & $(0.250)$ & $(0.019)$ & $(0.016)$ \\
\hline \multirow[t]{2}{*}{ Mom binge not known } & 0.117 & 0.002 & -0.005 & $0.654^{*}$ & 0.041 & 0.011 \\
\hline & $(0.299)$ & $(0.028)$ & $(0.022)$ & $(0.358)$ & $(0.026)$ & $(0.023)$ \\
\hline \multirow[t]{2}{*}{ Mom breast fed } & $-0.403 * * *$ & $-0.046 * * *$ & $-0.025 * *$ & $-0.458 * * *$ & -0.019 & $-0.035 * * *$ \\
\hline & $(0.146)$ & $(0.014)$ & $(0.011)$ & $(0.159)$ & $(0.013)$ & $(0.010)$ \\
\hline \multirow[t]{2}{*}{ Mom breast fed unknown } & -0.010 & 0.007 & 0.016 & 0.335 & 0.008 & $0.043 *$ \\
\hline & $(0.278)$ & $(0.027)$ & $(0.021)$ & $(0.345)$ & $(0.025)$ & $(0.022)$ \\
\hline \multirow[t]{2}{*}{ GPA } & $-0.303 * * *$ & $-0.028 * * *$ & $-0.018 * *$ & $-0.746 * * *$ & $-0.045 * * *$ & $-0.041 * * *$ \\
\hline & $(0.100)$ & $(0.009)$ & $(0.007)$ & $(0.119)$ & $(0.009)$ & $(0.008)$ \\
\hline \multirow[t]{2}{*}{ Took something from store w/o paying for it } & $-0.339 * *$ & -0.018 & -0.017 & $-0.334^{*}$ & $-0.040 * * *$ & -0.017 \\
\hline & $(0.142)$ & $(0.014)$ & $(0.011)$ & $(0.186)$ & $(0.014)$ & $(0.011)$ \\
\hline \multirow[t]{2}{*}{ Constant } & $28.665 * * *$ & 0.992 & $1.171^{*}$ & -0.118 & -1.320 & $-1.723 * * *$ \\
\hline & $(9.521)$ & $(0.856)$ & $(0.687)$ & (10.579) & $(0.813)$ & $(0.651)$ \\
\hline Observations & 6,442 & 6,442 & 6,442 & 7,157 & 7,157 & 7,157 \\
\hline R-squared & 0.077 & 0.055 & 0.048 & 0.126 & 0.106 & 0.087 \\
\hline
\end{tabular}

Robust standard errors in parentheses. ${ }^{* * *} \mathrm{p}<0.01,{ }^{* *} \mathrm{p}<0.05,{ }^{*} \mathrm{p}<0.1$. Benchmark categories: father's job is managerial/professional, income is unknown, parent's highest level of education is college or more. 
Table 4a: Propensity Score Models for Credit Card Debt

\section{Men Credit Card Debt}

\begin{tabular}{|c|c|c|c|c|c|c|c|c|c|}
\hline VARIABLES & OLS & $\begin{array}{c}\text { Nearest } \\
\text { Neighbor } \\
\end{array}$ & $\begin{array}{l}k \text { nearest } \\
\text { neighbor }\end{array}$ & $\begin{array}{c}\text { Within Caliper } \\
.001 \\
\end{array}$ & $\begin{array}{c}\text { Within Caliper } \\
.0001 \\
\end{array}$ & $\begin{array}{c}\text { Within Caliper } \\
.00005 \\
\end{array}$ & $\begin{array}{l}\text { Kernel } \\
\text { bw.06 }\end{array}$ & $\begin{array}{c}\text { LLR } \\
\text { bw .18 }\end{array}$ & $\begin{array}{c}\text { Radius } \\
\text { caliper .001 }\end{array}$ \\
\hline BMI & $\begin{array}{c}0.135 \\
(0.136)\end{array}$ & $\begin{array}{c}0.152 \\
(0.211)\end{array}$ & $\begin{array}{c}0.092 \\
(0.183)\end{array}$ & $\begin{array}{c}0.139 \\
(0.222)\end{array}$ & $\begin{array}{c}0.251 \\
(0.232)\end{array}$ & $\begin{array}{c}0.259 \\
(0.291)\end{array}$ & $\begin{array}{c}0.157 \\
(0.144)\end{array}$ & $\begin{array}{c}0.137 \\
(0.140)\end{array}$ & $\begin{array}{c}0.088 \\
(0.166)\end{array}$ \\
\hline Obese & $\begin{array}{c}0.006 \\
(0.010)\end{array}$ & $\begin{array}{l}-0.006 \\
(0.015)\end{array}$ & $\begin{array}{l}-0.003 \\
(0.013)\end{array}$ & $\begin{array}{l}-0.007 \\
(0.016)\end{array}$ & $\begin{array}{c}0.005 \\
(0.017)\end{array}$ & $\begin{array}{c}0.012 \\
(0.023)\end{array}$ & $\begin{array}{c}0.006 \\
(0.011)\end{array}$ & $\begin{array}{c}0.005 \\
(0.011)\end{array}$ & $\begin{array}{l}-0.001 \\
(0.012)\end{array}$ \\
\hline Overweight/Obese & $\begin{array}{c}0.026^{* *} \\
(0.013)\end{array}$ & $\begin{array}{c}0.047^{* *} \\
(0.019)\end{array}$ & $\begin{array}{c}0.033^{* *} \\
(0.016)\end{array}$ & $\begin{array}{c}0.046^{* *} \\
(0.019)\end{array}$ & $\begin{array}{c}0.044^{* *} \\
(0.022)\end{array}$ & $\begin{array}{c}0.040 \\
(0.028)\end{array}$ & $\begin{array}{c}0.029^{* *} \\
(0.014)\end{array}$ & $\begin{array}{c}0.029 * * \\
(0.014)\end{array}$ & $\begin{array}{l}0.026^{*} \\
(0.015)\end{array}$ \\
\hline $\begin{array}{l}\text { Observations } \\
\text { On common support }\end{array}$ & 6,442 & $\begin{array}{l}6,442 \\
6439\end{array}$ & $\begin{array}{l}6,442 \\
6439\end{array}$ & $\begin{array}{l}6,442 \\
6398\end{array}$ & $\begin{array}{l}6,442 \\
5718\end{array}$ & $\begin{array}{l}6,442 \\
5198\end{array}$ & $\begin{array}{l}6,442 \\
6439\end{array}$ & $\begin{array}{l}6,442 \\
6439\end{array}$ & $\begin{array}{l}6,442 \\
6398\end{array}$ \\
\hline
\end{tabular}

\section{Women Credit Card Debt}

\begin{tabular}{|c|c|c|c|c|c|c|c|c|c|}
\hline VARIABLES & OLS & $\begin{array}{l}\text { Nearest } \\
\text { Neighbor }\end{array}$ & $\begin{array}{l}k \text { nearest } \\
\text { neighbor }\end{array}$ & $\begin{array}{c}\text { Within Caliper } \\
.001\end{array}$ & $\begin{array}{c}\text { Within Caliper } \\
\quad .0001\end{array}$ & $\begin{array}{l}\text { Within Caliper } \\
.00005\end{array}$ & $\begin{array}{l}\text { Kernel } \\
\text { bw.06 }\end{array}$ & $\begin{array}{l}\text { LLR } \\
\text { bw .18 }\end{array}$ & $\begin{array}{c}\text { Radius } \\
\text { caliper .001 }\end{array}$ \\
\hline BMI & $\begin{array}{c}0.355^{* *} \\
(0.148)\end{array}$ & $\begin{array}{c}0.339 \\
(0.211)\end{array}$ & $\begin{array}{c}0.494^{* * * *} \\
(0.189)\end{array}$ & $\begin{array}{l}0.358^{*} \\
(0.205)\end{array}$ & $\begin{array}{c}0.168 \\
(0.275)\end{array}$ & $\begin{array}{c}0.213 \\
(0.319)\end{array}$ & $\begin{array}{c}0.418^{* *} \\
(0.164)\end{array}$ & $\begin{array}{c}0.381^{* *} \\
(0.154)\end{array}$ & $\begin{array}{c}0.431^{* *} \\
(0.168)\end{array}$ \\
\hline Obese & $\begin{array}{c}0.013 \\
(0.009)\end{array}$ & $\begin{array}{c}0.006 \\
(0.014)\end{array}$ & $\begin{array}{c}0.016 \\
(0.012)\end{array}$ & $\begin{array}{c}0.009 \\
(0.014)\end{array}$ & $\begin{array}{l}-0.006 \\
(0.017)\end{array}$ & $\begin{array}{l}-0.013 \\
(0.021)\end{array}$ & $\begin{array}{c}0.016 \\
(0.010)\end{array}$ & $\begin{array}{c}0.012 \\
(0.010)\end{array}$ & $\begin{array}{c}0.016 \\
(0.011)\end{array}$ \\
\hline Overweight/Obese & $\begin{array}{l}0.020^{*} \\
(0.012)\end{array}$ & $\begin{array}{c}0.014 \\
(0.017)\end{array}$ & $\begin{array}{c}0.026 \\
(0.016)\end{array}$ & $\begin{array}{c}0.016 \\
(0.017)\end{array}$ & $\begin{array}{c}0.005 \\
(0.022)\end{array}$ & $\begin{array}{c}0.016 \\
(0.026)\end{array}$ & $\begin{array}{l}0.023^{*} \\
(0.013)\end{array}$ & $\begin{array}{l}0.021^{*} \\
(0.013)\end{array}$ & $\begin{array}{l}0.022^{*} \\
(0.013)\end{array}$ \\
\hline Observations & 7,157 & 7,157 & 7,157 & 7,157 & 7,157 & 7,157 & 7,157 & 7,157 & 7,157 \\
\hline On common support & & 7157 & 7157 & 7100 & 6127 & 5393 & 7157 & 7157 & 7100 \\
\hline
\end{tabular}

Standard errors in parentheses*** $\mathrm{p}<0.01,{ }^{* *} \mathrm{p}<0.05,{ }^{*} \mathrm{p}<0.1$ 
Men Trouble Paying Bills

\begin{tabular}{|c|c|c|c|c|c|c|c|c|c|}
\hline VARIABLES & OLS & $\begin{array}{l}\text { Nearest } \\
\text { Neighbor }\end{array}$ & $\begin{array}{l}k \text { nearest } \\
\text { neighbor }\end{array}$ & $\begin{array}{c}\text { Within } \\
\text { Caliper } \\
.001 \\
\end{array}$ & $\begin{array}{l}\text { Within } \\
\text { Caliper } \\
.0001 \\
\end{array}$ & $\begin{array}{l}\text { Within } \\
\text { Caliper } \\
.00005 \\
\end{array}$ & $\begin{array}{l}\text { Kernel } \\
\text { bw.06 }\end{array}$ & $\begin{array}{l}\text { LLR bw } \\
.18\end{array}$ & $\begin{array}{c}\text { Radius caliper } \\
.001\end{array}$ \\
\hline BMI & $\begin{array}{l}-0.103 \\
(0.150)\end{array}$ & $\begin{array}{l}-0.050 \\
(0.209)\end{array}$ & $\begin{array}{l}-0.111 \\
(0.206)\end{array}$ & $\begin{array}{l}-0.072 \\
(0.235)\end{array}$ & $\begin{array}{c}0.013 \\
(0.256)\end{array}$ & $\begin{array}{c}0.041 \\
(0.304)\end{array}$ & $\begin{array}{l}-0.087 \\
(0.163)\end{array}$ & $\begin{array}{l}-0.066 \\
(0.163)\end{array}$ & $\begin{array}{l}-0.151 \\
(0.172)\end{array}$ \\
\hline Obese & $\begin{array}{l}-0.003 \\
(0.011)\end{array}$ & $\begin{array}{c}0.006 \\
(0.016)\end{array}$ & $\begin{array}{l}-0.005 \\
(0.014)\end{array}$ & $\begin{array}{c}0.004 \\
(0.017)\end{array}$ & $\begin{array}{c}0.001 \\
(0.019)\end{array}$ & $\begin{array}{c}0.014 \\
(0.024)\end{array}$ & $\begin{array}{l}-0.001 \\
(0.011)\end{array}$ & $\begin{array}{c}0.000 \\
(0.011)\end{array}$ & $\begin{array}{l}-0.000 \\
(0.012)\end{array}$ \\
\hline Overweight/Obese & $\begin{array}{c}-0.041^{* * *} \\
(0.014)\end{array}$ & $\begin{array}{c}-0.042 * * \\
(0.021)\end{array}$ & $\begin{array}{c}-0.045 * * \\
(0.019)\end{array}$ & $\begin{array}{c}-0.047^{* *} * \\
(0.021)\end{array}$ & $\begin{array}{l}-0.043^{*} \\
(0.023)\end{array}$ & $\begin{array}{l}-0.045 \\
(0.029)\end{array}$ & $\begin{array}{c}-0.038 * * * \\
(0.015)\end{array}$ & $\begin{array}{c}-0.035^{* *} \\
(0.015)\end{array}$ & $\begin{array}{c}-0.043 * * * \\
(0.015)\end{array}$ \\
\hline $\begin{array}{l}\text { Observations } \\
\text { On common support }\end{array}$ & 6,442 & $\begin{array}{l}6,442 \\
6440\end{array}$ & $\begin{array}{l}6,442 \\
6440\end{array}$ & $\begin{array}{l}6,442 \\
6402\end{array}$ & $\begin{array}{l}6,442 \\
5975\end{array}$ & $\begin{array}{l}6,442 \\
5643\end{array}$ & $\begin{array}{l}6,442 \\
6440\end{array}$ & $\begin{array}{l}6,442 \\
6440\end{array}$ & $\begin{array}{l}6,442 \\
6402\end{array}$ \\
\hline & & \multicolumn{8}{|c|}{ Women Trouble Paying Bills } \\
\hline VARIABLES & OLS & $\begin{array}{c}\text { Nearest } \\
\text { Neighbor }\end{array}$ & $\begin{array}{l}\text { k nearest } \\
\text { neighbor }\end{array}$ & $\begin{array}{c}\text { Within } \\
\text { Caliper } \\
.001 \\
\end{array}$ & $\begin{array}{c}\text { Within } \\
\text { Caliper } \\
.0001 \\
\end{array}$ & $\begin{array}{l}\text { Within } \\
\text { Caliper } \\
.00005 \\
\end{array}$ & $\begin{array}{l}\text { Kernel } \\
\text { bw .06 }\end{array}$ & $\begin{array}{l}\text { LLR bw } \\
.18\end{array}$ & $\begin{array}{c}\text { Radius } \\
\text { Caliper .001 }\end{array}$ \\
\hline BMI & $\begin{array}{c}0.727 * * * \\
(0.161)\end{array}$ & $\begin{array}{l}0.608 * * \\
(0.240)\end{array}$ & $\begin{array}{c}0.741^{* * *} \\
(0.224)\end{array}$ & $\begin{array}{c}0.551^{* *} \\
(0.236)\end{array}$ & $\begin{array}{c}0.596 * * \\
(0.274)\end{array}$ & $\begin{array}{l}0.641 * \\
(0.345)\end{array}$ & $\begin{array}{c}0.824 * * * \\
(0.185)\end{array}$ & $\begin{array}{c}0.836 * * * \\
(0.176)\end{array}$ & $\begin{array}{c}0.725 * * * \\
(0.194)\end{array}$ \\
\hline Obese & $\begin{array}{c}0.040 * * * \\
(0.011)\end{array}$ & $\begin{array}{l}0.036 * * \\
(0.015)\end{array}$ & $\begin{array}{c}0.041 * * * \\
(0.015)\end{array}$ & $\begin{array}{c}0.033 * * \\
(0.016)\end{array}$ & $\begin{array}{l}0.039 * * \\
(0.018)\end{array}$ & $\begin{array}{l}0.044^{*} \\
(0.023)\end{array}$ & $\begin{array}{c}0.042 * * * \\
(0.012)\end{array}$ & $\begin{array}{c}0.043^{* * *} \\
(0.011)\end{array}$ & $\begin{array}{c}0.039 * * * \\
(0.013)\end{array}$ \\
\hline Overweight/Obese & $\begin{array}{c}0.047 * * * \\
(0.013)\end{array}$ & $\begin{array}{c}0.037 * * \\
(0.018)\end{array}$ & $\begin{array}{c}0.038 * * \\
(0.016)\end{array}$ & $\begin{array}{c}0.037 * * \\
(0.018)\end{array}$ & $\begin{array}{c}0.034 \\
(0.022)\end{array}$ & $\begin{array}{c}0.035 \\
(0.026)\end{array}$ & $\begin{array}{c}0.052 * * * \\
(0.013)\end{array}$ & $\begin{array}{c}0.051 * * * \\
(0.013)\end{array}$ & $\begin{array}{c}0.049 * * * \\
(0.014)\end{array}$ \\
\hline Observations & 7,157 & 7,157 & 7,157 & 7,157 & 7,157 & 7,157 & 7,157 & 7,157 & 7,157 \\
\hline On common support & & 7157 & 7157 & 7094 & 6495 & 6007 & 7157 & 7157 & 7094 \\
\hline
\end{tabular}

Standard errors in parentheses ${ }^{* * *} \mathrm{p}<0.01,{ }^{* *} \mathrm{p}<0.05,{ }^{*} \mathrm{p}<0.1$ 
Table 5. Rosenbaum Bounds Sensitivity Test

Outcome: Overweight or Obese

\begin{tabular}{|l|c|c|c|c|}
\hline $\mathrm{e}^{\gamma}$ & $\begin{array}{c}\text { P-values } \\
\text { (Women Credit Card Debt) }\end{array}$ & $\begin{array}{c}\text { P-values } \\
\text { (Men Credit Card } \\
\text { Debt) }\end{array}$ & $\begin{array}{c}\text { P-values } \\
\text { (Women Trouble } \\
\text { paying bills) }\end{array}$ & $\begin{array}{c}\text { P-values } \\
\text { (Men Trouble paying } \\
\text { bills) }\end{array}$ \\
\hline$\gamma=1$ & 0.000909 & 0.000013 & 0 & 0.001043 \\
\hline$\gamma=1.05$ & 0.01763 & 0.000549 & $2.20 \mathrm{E}-15$ & 0.000036 \\
\hline$\gamma=1.10$ & 0.127251 & 0.009157 & $2.30 \mathrm{E}-12$ & $7.00 \mathrm{E}-07$ \\
\hline$\gamma=1.15$ & 0.414214 & 0.067465 & $7.90 \mathrm{E}-10$ & $8.50 \mathrm{E}-09$ \\
\hline$\gamma=1.20$ & 0.268103 & 0.25218 & $1.00 \mathrm{E}-07$ & $3.60 \mathrm{E}-13$ \\
\hline$\gamma=1.25$ & 0.071322 & 0.470373 & $5.80 \mathrm{E}-06$ & 0 \\
\hline$\gamma=1.30$ & 0.011293 & 0.201406 & 0.000154 & 0 \\
\hline$\gamma=1.35$ & 0.001091 & 0.058183 & 0.0021 & 0 \\
\hline$\gamma=1.40$ & 0.000067 & 0.011385 & 0.016017 & 0 \\
\hline$\gamma=1.45$ & $2.70 \mathrm{E}-06$ & 0.001539 & 0.073437 & 0 \\
\hline$\gamma=1.50$ & $7.40 \mathrm{E}-08$ & 0.000148 & 0.217404 & 0 \\
\hline$\gamma=1.55$ & $1.50 \mathrm{E}-09$ & 0.00001 & 0.446959 & 0 \\
\hline$\gamma=1.60$ & $2.10 \mathrm{E}-11$ & $5.40 \mathrm{E}-07$ & 0.328857 & 0 \\
\hline$\gamma=1.65$ & $2.30 \mathrm{E}-13$ & $2.20 \mathrm{E}-08$ & 0.146662 & 0 \\
\hline$\gamma=1.70$ & $1.90 \mathrm{E}-15$ & $6.90 \mathrm{E}-10$ & 0.050443 & 0 \\
\hline$\gamma=1.75$ & 0 & $1.80 \mathrm{E}-11$ & 0.013438 & 0 \\
\hline$\gamma=1.80$ & 0 & $3.70 \mathrm{E}-13$ & 0.002802 & 0 \\
\hline$\gamma=1.85$ & $0.30 \mathrm{E}-15$ & 0.000464 & 0.000062 & 0 \\
\hline$\gamma=1.90$ & 0 & $1.10 \mathrm{E}-16$ & $0.70 \mathrm{E}-06$ & 0 \\
\hline$\gamma=1.95$ & 0 & 0 & $6.00 \mathrm{E}-07$ & 0 \\
\hline$\gamma=2$ & 0 & 0 & 0 & 0 \\
\hline
\end{tabular}

These results assess the sensitivity of the kernel matching because this is the matching method most often recommended in the literature (Henry and Yi, 2009) 
Table 6: Differences in Means by Gender and Financial Hardship Measure holding Impulsivity Constant

\begin{tabular}{|c|c|c|c|c|}
\hline \multirow[t]{2}{*}{ Wave III: Women } & \multicolumn{2}{|c|}{ Impulsive $^{\mathrm{a}}$} & \multicolumn{2}{|c|}{ Non-impulsive ${ }^{\mathrm{b}}$} \\
\hline & Credit Card Debt & Trouble Paying Bills & Credit Card Debt & Trouble Paying Bills \\
\hline Married & 0.0110 & 0.0001 & 0.142 & 0.4448 \\
\hline Gambled & 0.0000 & 0.5181 & 0.6292 & 0.9798 \\
\hline Has a savings account & 0.0078 & 0.0085 & 0.0312 & 0.1465 \\
\hline Volunteers & 0.0519 & 0.2393 & 0.5486 & 0.4046 \\
\hline Income between $\$ 1$ and $\$ 7$ & 0.9172 & 0.5452 & 0.1871 & 0.1774 \\
\hline Income between $\$ 8$ and $\$ 3900$ & 0.4408 & 0.3781 & 0.7473 & 0.6351 \\
\hline Income between $\$ 4000$ and $\$ 11700$ & 0.2286 & 0.0100 & 0.2268 & 0.7934 \\
\hline Income between $\$ 12000$ and $\$ 20100$ & 0.4154 & 0.1803 & 0.3112 & 0.6088 \\
\hline Income between $\$ 20500$ and $\$ 300000$ & 0.0155 & 0.0013 & 0.0213 & 0.9779 \\
\hline Income missing & 0.0802 & 0.8347 & 0.9317 & 0.0222 \\
\hline Played the lottery & 0.0000 & 0.0010 & 0.1529 & 0.7278 \\
\hline Religiosity & 0.4185 & 0.0136 & 0.2862 & 0.6966 \\
\hline White & 0.1300 & 0.0698 & 0.3011 & 0.7180 \\
\hline Black & 0.0381 & 0.0711 & 0.3733 & 0.5749 \\
\hline Other race & 0.3604 & 0.8566 & 0.7462 & 0.7849 \\
\hline Hispanic & 0.6970 & 0.7315 & 0.8778 & 0.2162 \\
\hline Has a credit card & & 0.0000 & & 0.1117 \\
\hline \multirow[t]{2}{*}{$\mathrm{N}$} & 759 & 759 & 170 & 170 \\
\hline & \multicolumn{2}{|c|}{ Impulsive } & \multicolumn{2}{|c|}{ Non-impulsive } \\
\hline Men & Credit Card Debt & Trouble Paying Bills & Credit Card Debt & Trouble Paying Bills \\
\hline Married & 0.2369 & 0.2936 & 0.4224 & 0.1791 \\
\hline Gambled & 0.0885 & 0.0021 & 0.3652 & 0.0149 \\
\hline Has a savings account & 0.009 & 0.018 & 0.0157 & 0.0075 \\
\hline Volunteers & 0.5525 & 0.5491 & 0.7582 & 0.818 \\
\hline Income between $\$ 1$ and \$7 & 0.1211 & 0.0127 & 0.0355 & 0.0315 \\
\hline Income between $\$ 8$ and $\$ 3900$ & 0.2924 & 0.4044 & 0.4634 & 0.4299 \\
\hline Income between $\$ 4000$ and $\$ 11700$ & 0.5155 & 0.0002 & 0.6334 & 0.0022 \\
\hline Income between $\$ 12000$ and $\$ 20100$ & 0.337 & 0.2126 & 0.1542 & 0.4869 \\
\hline Income between $\$ 20500$ and $\$ 300000$ & 0.2803 & 0.42 & 0.5504 & 0.6786 \\
\hline Income missing & 0.2009 & 0.1225 & 0.1934 & 0.4785 \\
\hline Played the lottery & 0.057 & 0.0075 & 0.1604 & 0.019 \\
\hline Religiosity & 0.3425 & 0.6198 & 0.3623 & 0.4134 \\
\hline White & 0.6910 & 0.7669 & 0.7605 & 0.8971 \\
\hline Black & 0.2020 & 0.8256 & 0.9929 & 0.4312 \\
\hline Other race & 0.2486 & 0.8872 & 0.6468 & 0.3558 \\
\hline Hispanic & 0.9490 & 0.0127 & 0.0150 & 0.9600 \\
\hline Has a credit card & & 0.5928 & & 0.6433 \\
\hline $\mathrm{N}$ & 277 & 277 & 262 & 262 \\
\hline
\end{tabular}

Cell entries are p-values for the null hypothesis that the variable means are equal within impulsivity and gender but across financial hardship measures.

aimplusive $=1$ when score $=15$ if answered 3 questions, $=10$ if answered 2 questions, $=5$ if answered 1 question

bon-implusive $=1$ if score $=3$ if answered 3 questions, $=2$ if answered 2 questions, $=1$ if answered 1 question 
Table 7: Sensitivity of Treatment effects to unobservable characteristics

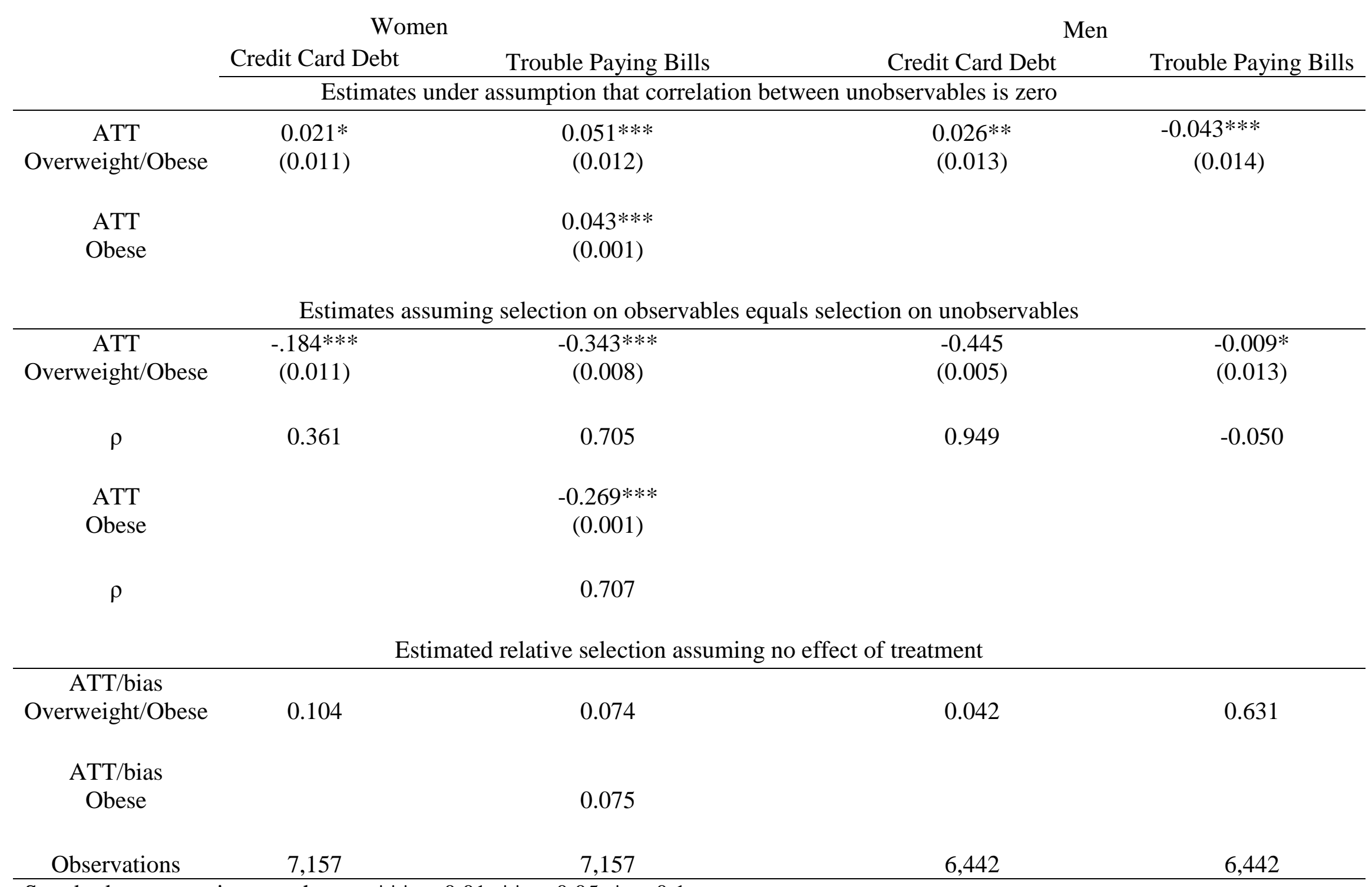

Standard errors are in parentheses. ${ }^{* * *} \mathrm{p}<0.01,{ }^{* *} \mathrm{p}<0.05,{ }^{*} \mathrm{p}<0.1$

Estimates shown are marginal effects. 
In Wave III, respondents are asked:

- In the past 12 months, was there a time when \{YOU WERE/YOUR HOUSEHOLD WAS \} without telephone service for any reason?

- In the past 12 months, was there a time when \{YOU WERE/YOUR HOUSEHOLD WAS \} didn't pay the full amount of the rent or mortgage because you didn't have enough money?

- In the past 12 months, was there a time when \{YOU WERE/YOUR HOUSEHOLD WAS \} evicted from your house or apartment for not paying the rent or mortgage?

- In the past 12 months, was there a time when \{YOU WERE/YOUR HOUSEHOLD\} didn't pay the full amount of a gas, electricity, or oil bill because you didn't have enough money?

- In the past 12 months, was there a time when \{YOU WERE/YOUR HOUSEHOLD WAS \} had the service turned off by the gas or electric company, or the oil company wouldn't deliver, because payments were not made?

- In the past 12 months, was there a time when \{YOU/SOMEONE IN YOUR HOUSEHOLD\} needed to see a doctor or go to the hospital, but didn't go because $\{$ YOU/THEY $\}$ could not afford it?

- In the past 12 months, was there a time when \{YOU/SOMEONE IN YOUR HOUSEHOLD\} needed to see a dentist, but didn't go because \{YOU/THEY\} could not afford it?

Respondents who answer a yes to one or more of the above, are coded has having had trouble paying their bills. 
Wave III Respondents are asked:

How true do you think each of the following statements is of you?

- I often try new things just for fun or thrills, even if most people think they are a waste of time

- When nothing new is happening, I usually start looking for something exciting

- I can usually get people to believe me, even when what I'm saying isn't quite true.

- I often do things based on how I feel at the moment

- I sometimes get so excited that I lose control of myself

- I like it when people can do whatever they want, without strict rules and regulations

- I often follow my instincts, without thinking through all the details

- I can do a good job of "stretching the truth" when I'm talking to people

- I change my interest a lot, because my attention often shifts to something else

Possible answers (given below) are summed into an index using the alpha command in Stata 11 . The index has a scale reliability coefficient of 0.9136 (Chronbach’s alpha).

$1=$ not true

$2=$ a little true

$3=$ somewhat true

$4=$ pretty true

$5=$ very true 
Appendix Table 3: Cross tabulations of credit card debt and having trouble paying bills

\section{Key}

frequency

row percentage

column percentage

Men

\begin{tabular}{c|ccc}
\multirow{2}{*}{ Trouble Paying Bills } & \multicolumn{3}{|c}{ Credit Card Debt } \\
\hline \multirow{3}{*}{0} & 2,873 & 1,667 & Total \\
\hline \multirow{3}{*}{1} & 63.28 & 36.72 & 100.00 \\
& 72.2 & 67.68 & 70.48 \\
\hline \multirow{2}{*}{ Total } & 1,106 & 796 & 1,902 \\
& 58.15 & 41.85 & 100.00 \\
& 27.8 & 32.32 & 29.52 \\
\hline & 3,979 & 2,463 & 6,442 \\
& 61.77 & 38.23 & 100.00 \\
& 100.00 & 100.00 & 100.00
\end{tabular}

\begin{tabular}{c|ccc}
\multirow{2}{*}{ Trouble Paying Bills } & \multicolumn{3}{|c}{ Credit Card Debt } \\
\hline \multirow{2}{*}{0} & 0 & 1 & Total \\
\hline \multirow{3}{*}{1} & 57.743 & 2,025 & 4,768 \\
& 69.30 & 42.47 & 100.00 \\
& 1,215 & 1,174 & 2,389 \\
Total & 50.86 & 49.14 & 100.00 \\
& 30.70 & 36.70 & 33.38 \\
\hline \multirow{3}{*}{1,958} & 3,199 & 7,157 \\
& 55.30 & 44.70 & 100.00 \\
& 100.00 & 100.00 & 100.00
\end{tabular}


Appendix Table 4: Logit Estimation for Calculation of the Propensity Score

\begin{tabular}{|c|c|c|c|c|}
\hline VARIABLES & $\begin{array}{c}\text { Men } \\
\text { Credit Card } \\
\text { Debt }\end{array}$ & $\begin{array}{c}\text { Women } \\
\text { Credit Card } \\
\text { Debt }\end{array}$ & $\begin{array}{c}\text { Men } \\
\text { Trouble Paying } \\
\text { Bills }\end{array}$ & $\begin{array}{c}\text { Women } \\
\text { Trouble } \\
\text { paying bills }\end{array}$ \\
\hline Age & $\begin{array}{c}2.489 * * * \\
(0.374)\end{array}$ & $\begin{array}{c}1.902 * * * \\
(0.352)\end{array}$ & $\begin{array}{c}0.568 \\
(0.374)\end{array}$ & $\begin{array}{c}0.528 \\
(0.361)\end{array}$ \\
\hline Age squared & $\begin{array}{c}-0.053^{* * *} \\
(0.008)\end{array}$ & $\begin{array}{c}-0.041^{* * *} \\
(0.008)\end{array}$ & $\begin{array}{l}-0.011 \\
(0.008)\end{array}$ & $\begin{array}{l}-0.011 \\
(0.008)\end{array}$ \\
\hline Married & $\begin{array}{c}0.465^{* * * *} \\
(0.078)\end{array}$ & $\begin{array}{c}0.401^{* * * *} \\
(0.065)\end{array}$ & $\begin{array}{c}0.183 * * \\
(0.084)\end{array}$ & $\begin{array}{c}0.325^{* * *} \\
(0.068)\end{array}$ \\
\hline Inc. between $\$ 1$-\$7 & $\begin{array}{c}0.175 \\
(0.155)\end{array}$ & $\begin{array}{c}0.185 \\
(0.150)\end{array}$ & $\begin{array}{c}0.400 * * \\
(0.159)\end{array}$ & $\begin{array}{c}0.171 \\
(0.154)\end{array}$ \\
\hline Inc. between $\$ 8-\$ 3900$ & $\begin{array}{c}0.191 \\
(0.153)\end{array}$ & $\begin{array}{c}0.238 \\
(0.150)\end{array}$ & $\begin{array}{l}0.275^{*} \\
(0.158)\end{array}$ & $\begin{array}{c}0.111 \\
(0.155)\end{array}$ \\
\hline Inc. btw $\$ 4000-\$ 11700$ & $\begin{array}{c}0.229 \\
(0.153)\end{array}$ & $\begin{array}{c}0.443 * * * \\
(0.150)\end{array}$ & $\begin{array}{c}0.473 * * * \\
(0.158)\end{array}$ & $\begin{array}{l}0.349 * * \\
(0.155)\end{array}$ \\
\hline Inc. btw $\$ 12000-\$ 20100$ & $\begin{array}{c}0.536^{* * * *} \\
(0.149)\end{array}$ & $\begin{array}{c}0.700^{* * * *} \\
(0.150)\end{array}$ & $\begin{array}{c}0.354 * * \\
(0.155)\end{array}$ & $\begin{array}{c}0.240 \\
(0.155)\end{array}$ \\
\hline Income missing & $\begin{array}{c}0.668^{* * * *} \\
(0.148)\end{array}$ & $\begin{array}{c}0.712 * * * \\
(0.154)\end{array}$ & $\begin{array}{l}-0.042 \\
(0.157)\end{array}$ & $\begin{array}{l}-0.116 \\
(0.162)\end{array}$ \\
\hline Gamble & $\begin{array}{c}0.195 * * * \\
(0.064)\end{array}$ & $\begin{array}{c}0.297 * * * \\
(0.056)\end{array}$ & $\begin{array}{c}0.059 \\
(0.067)\end{array}$ & $\begin{array}{c}0.009 \\
(0.060)\end{array}$ \\
\hline Has savings account & $\begin{array}{c}0.139 * * \\
(0.058)\end{array}$ & $\begin{array}{c}-0.024 \\
(0.055)\end{array}$ & $\begin{array}{c}-0.367 * * * \\
(0.060)\end{array}$ & $\begin{array}{c}-0.429 * * * \\
(0.057)\end{array}$ \\
\hline Lottery & $\begin{array}{c}0.355^{* * * *} \\
(0.064)\end{array}$ & $\begin{array}{c}0.397 * * * \\
(0.057)\end{array}$ & $\begin{array}{l}0.119 * \\
(0.067)\end{array}$ & $\begin{array}{c}0.129 * * \\
(0.060)\end{array}$ \\
\hline Propensity to take risks & $\begin{array}{c}0.046 \\
(0.031)\end{array}$ & $\begin{array}{l}-0.020 \\
(0.030)\end{array}$ & $\begin{array}{c}0.168 * * * \\
(0.032)\end{array}$ & $\begin{array}{c}0.208^{* * * *} \\
(0.031)\end{array}$ \\
\hline Religious & $\begin{array}{l}-0.044 \\
(0.031)\end{array}$ & $\begin{array}{l}-0.023 \\
(0.029)\end{array}$ & $\begin{array}{c}-0.067 * * \\
(0.032)\end{array}$ & $\begin{array}{l}-0.051^{*} \\
(0.031)\end{array}$ \\
\hline Black & $\begin{array}{c}0.003 \\
(0.079)\end{array}$ & $\begin{array}{c}0.359 * * * \\
(0.070)\end{array}$ & $\begin{array}{c}0.067 \\
(0.081)\end{array}$ & $\begin{array}{c}0.193 * * * \\
(0.073)\end{array}$ \\
\hline Other race & $\begin{array}{c}-0.192^{* *} \\
(0.088)\end{array}$ & $\begin{array}{c}0.047 \\
(0.087)\end{array}$ & $\begin{array}{l}-0.040 \\
(0.093)\end{array}$ & $\begin{array}{l}-0.087 \\
(0.096)\end{array}$ \\
\hline Hispanic & $\begin{array}{c}0.476 * * * \\
(0.081)\end{array}$ & $\begin{array}{c}0.411^{* * *} \\
(0.078)\end{array}$ & $\begin{array}{l}-0.146 * \\
(0.087)\end{array}$ & $\begin{array}{c}-0.038 \\
(0.082)\end{array}$ \\
\hline Drank in past 30 days & $\begin{array}{c}-0.133 \\
(0.089)\end{array}$ & $\begin{array}{c}-0.165 \\
(0.101)\end{array}$ & $\begin{array}{l}-0.133 \\
(0.093)\end{array}$ & $\begin{array}{l}-0.046 \\
(0.104)\end{array}$ \\
\hline Thinks smart compared to others & $\begin{array}{c}0.223^{* * * *} \\
(0.060)\end{array}$ & $\begin{array}{c}0.230 * * * \\
(0.056)\end{array}$ & $\begin{array}{c}0.077 \\
(0.063)\end{array}$ & $\begin{array}{c}0.138 * * \\
(0.059)\end{array}$ \\
\hline Likely to go to college & $\begin{array}{c}0.044 \\
(0.060)\end{array}$ & $\begin{array}{c}0.131 * * \\
(0.058)\end{array}$ & $\begin{array}{c}-0.285^{* * *} \\
(0.063)\end{array}$ & $\begin{array}{c}-0.297 * * * \\
(0.059)\end{array}$ \\
\hline Usual summer work hrs & $\begin{array}{c}0.004 * * \\
(0.002)\end{array}$ & $\begin{array}{c}0.007 * * * \\
(0.002)\end{array}$ & $\begin{array}{c}0.002 \\
(0.002)\end{array}$ & $\begin{array}{c}0.005^{* *} \\
(0.002)\end{array}$ \\
\hline
\end{tabular}




\begin{tabular}{|c|c|c|c|c|}
\hline Dad unemployed & $\begin{array}{c}0.251 \\
(0.157)\end{array}$ & $\begin{array}{c}0.073 \\
(0.154)\end{array}$ & $\begin{array}{c}0.174 \\
(0.158)\end{array}$ & $\begin{array}{c}0.335 * * \\
(0.158)\end{array}$ \\
\hline Dad job unknown & $\begin{array}{c}0.246 * * * \\
(0.091)\end{array}$ & $\begin{array}{c}0.199 * * \\
(0.085)\end{array}$ & $\begin{array}{c}0.127 \\
(0.097)\end{array}$ & $\begin{array}{c}0.389 * * * \\
(0.093)\end{array}$ \\
\hline Dad job other than manag/prof & $\begin{array}{c}0.120 \\
(0.079)\end{array}$ & $\begin{array}{c}0.179 * * \\
(0.076)\end{array}$ & $\begin{array}{c}-0.038 \\
(0.086)\end{array}$ & $\begin{array}{c}0.112 \\
(0.085)\end{array}$ \\
\hline Smoked in high school & $\begin{array}{c}-0.135 * \\
(0.075)\end{array}$ & $\begin{array}{l}-0.101 \\
(0.072)\end{array}$ & $\begin{array}{c}0.340 * * * \\
(0.075)\end{array}$ & $\begin{array}{c}0.319 * * * \\
(0.073)\end{array}$ \\
\hline Parent has some college & $\begin{array}{c}0.071 \\
(0.076)\end{array}$ & $\begin{array}{l}0.120 * \\
(0.071)\end{array}$ & $\begin{array}{c}0.032 \\
(0.081)\end{array}$ & $\begin{array}{c}0.079 \\
(0.077)\end{array}$ \\
\hline Parent educ. HS graduate & $\begin{array}{c}-0.157 * * \\
(0.074)\end{array}$ & $\begin{array}{l}-0.018 \\
(0.070)\end{array}$ & $\begin{array}{c}0.065 \\
(0.077)\end{array}$ & $\begin{array}{c}0.123^{*} \\
(0.074)\end{array}$ \\
\hline Parent educ. less than HS & $\begin{array}{c}-0.319 * * * \\
(0.112)\end{array}$ & $\begin{array}{c}-0.291 * * * \\
(0.100)\end{array}$ & $\begin{array}{c}0.051 \\
(0.115)\end{array}$ & $\begin{array}{c}0.111 \\
(0.103)\end{array}$ \\
\hline Parent's Education Unknown & $\begin{array}{l}-0.147 \\
(0.166)\end{array}$ & $\begin{array}{c}-0.831 * * * \\
(0.182)\end{array}$ & $\begin{array}{c}0.103 \\
(0.164)\end{array}$ & $\begin{array}{l}-0.117 \\
(0.171)\end{array}$ \\
\hline Parent received welfare & $\begin{array}{c}-0.259 * * \\
(0.102)\end{array}$ & $\begin{array}{c}-0.363 * * * \\
(0.091)\end{array}$ & $\begin{array}{c}0.447 * * * \\
(0.096)\end{array}$ & $\begin{array}{c}0.158^{*} \\
(0.088)\end{array}$ \\
\hline Parent smoked & $\begin{array}{c}0.031 \\
(0.069)\end{array}$ & $\begin{array}{c}-0.034 \\
(0.064)\end{array}$ & $\begin{array}{c}0.127^{*} \\
(0.071)\end{array}$ & $\begin{array}{c}0.268^{* * *} \\
(0.066)\end{array}$ \\
\hline Mom obese & $\begin{array}{c}0.048 \\
(0.076)\end{array}$ & $\begin{array}{c}0.090 \\
(0.070)\end{array}$ & $\begin{array}{c}0.041 \\
(0.080)\end{array}$ & $\begin{array}{c}0.115 \\
(0.073)\end{array}$ \\
\hline Mom binge drinker & $\begin{array}{l}-0.026 \\
(0.092)\end{array}$ & $\begin{array}{c}0.006 \\
(0.086)\end{array}$ & $\begin{array}{c}0.014 \\
(0.094)\end{array}$ & $\begin{array}{c}0.021 \\
(0.088)\end{array}$ \\
\hline Mom binge drinker unknown & $\begin{array}{c}-0.129 \\
(0.124)\end{array}$ & $\begin{array}{c}0.006 \\
(0.117)\end{array}$ & $\begin{array}{c}0.025 \\
(0.129)\end{array}$ & $\begin{array}{c}0.116 \\
(0.120)\end{array}$ \\
\hline Mom breast fed & $\begin{array}{c}0.059 \\
(0.062)\end{array}$ & $\begin{array}{c}0.087 \\
(0.058)\end{array}$ & $\begin{array}{c}0.005 \\
(0.066)\end{array}$ & $\begin{array}{c}0.068 \\
(0.062)\end{array}$ \\
\hline Mom breast fed unknown & $\begin{array}{c}0.156 \\
(0.117)\end{array}$ & $\begin{array}{c}0.000 \\
(0.114)\end{array}$ & $\begin{array}{l}-0.030 \\
(0.122)\end{array}$ & $\begin{array}{c}0.101 \\
(0.117)\end{array}$ \\
\hline High school GPA & $\begin{array}{c}0.123 * * * \\
(0.042)\end{array}$ & $\begin{array}{c}0.053 \\
(0.041)\end{array}$ & $\begin{array}{l}-0.047 \\
(0.044)\end{array}$ & $\begin{array}{c}-0.107 * * \\
(0.042)\end{array}$ \\
\hline Took something from store w/o paying for it & $\begin{array}{c}0.219 * * * \\
(0.061)\end{array}$ & $\begin{array}{c}0.088 \\
(0.064)\end{array}$ & $\begin{array}{c}0.254^{* * *} * \\
(0.063)\end{array}$ & $\begin{array}{c}0.153 * * \\
(0.066)\end{array}$ \\
\hline Volunteers & & $\begin{array}{c}0.012 \\
(0.058)\end{array}$ & & $\begin{array}{c}0.090 \\
(0.062)\end{array}$ \\
\hline Has a Credit card & & & $\begin{array}{c}-0.281^{* * *} \\
(0.063)\end{array}$ & $\begin{array}{c}-0.510 * * * \\
(0.059)\end{array}$ \\
\hline Constant & $\begin{array}{c}-30.967 * * * \\
(4.131)\end{array}$ & $\begin{array}{c}-23.732 * * * \\
(3.849)\end{array}$ & $\begin{array}{c}-8.495 * * \\
(4.110)\end{array}$ & $\begin{array}{l}-7.258 * \\
(3.944)\end{array}$ \\
\hline Observations & 6,442 & 7,157 & 6,442 & 7,157 \\
\hline
\end{tabular}

